\title{
Hydrogeochemical characteristics and spatial distribution of groundwater quality in Arusha well fields, Northern Tanzania
}

\author{
Nyamboge Chacha ${ }^{1,3} \cdot$ Karoli N. Njau $^{1} \cdot$ George V. Lugomela ${ }^{2} \cdot$ Alfred N. N. Muzuka $^{1}$
}

Received: 25 October 2017 / Accepted: 25 June 2018 / Published online: 9 July 2018

(c) The Author(s) 2018

\begin{abstract}
Arusha aquifers have been exploited intensively serving as the main source of domestic water supply in the city. But the quality of groundwater is not clearly documented for future planning and management. Hydrogeochemical assessment was carried out to establish groundwater quality and its spatial distribution with the aid of geostatistical techniques. Groundwater samples were collected and analyzed for major cations and anions using conventional methods of water analysis. Well lithology and geological map were considered for hydrogeological interpretation of the area. The results of piper diagram revealed $\mathrm{Na}-\mathrm{K}-\mathrm{HCO}_{3}$ water type with sodium and bicarbonate ions dominating in all samples. High fluoride concentrations and general groundwater chemistry are mainly controlled by aquifer lithology than anthropogenic activities. The levels of anthropogenic pollution indicators such as nitrate, chloride and sulfate in deep wells are generally low and most likely coming from natural sources. The geological sections indicate two potential aquifers (volcanic sediment and weathered/ fractured formation) both yield water containing significant concentration of fluoride. Fluoride concentrations were higher than WHO guidelines $(1.5 \mathrm{mg} / \mathrm{l})$ and Tanzanian standards $(4.0 \mathrm{mg} / \mathrm{l})$ by 82 and $36 \%$ of the analyzed groundwater samples, respectively. The southern part of the study area yields groundwater of better quality for human consumption than northern zones which is at high elevation on the foot of Mt. Meru. With exception of fluoride, the quality of groundwater in the study area is generally suitable for drinking purpose and other socioeconomic uses.
\end{abstract}

Keywords Groundwater quality $\cdot$ Hydrogeochemical $\cdot$ Arusha

\section{Introduction}

Water is the most important natural resource for continued existence of any community or ecosystem (Gleeson et al. 2016; Jha et al. 2007; Kløve et al. 2014). Most social economic processes and functions of a particular community are largely depending on potable water supply (Brown and Lall 2006; Chenoweth 2008; Komakech et al. 2012). Its vital role necessitates the importance of understanding water resources dynamics throughout the world for present and

Nyamboge Chacha

chachan@nm-aist.ac.tz; cnmakuri@gmail.com

Department of Water, Environmental Science and Engineering, Nelson Mandela African Institution of Science and Technology, Arusha, Tanzania

2 Ministry of Water and Irrigation, P.O. Box 14473, Dar es Salaam, Tanzania

3 Department of Environmental Engineering, Ardhi University, P.O. Box 35176, Dar es Salaam, Tanzania future use (Heathwaite 2010; Hellar-Kihampa et al. 2013; Schmoll 2006). Due to socioeconomic development, rapid population growth and increased incidences of freshwater pollution (Schwarzenbach et al. 2010), groundwater exploitation has increased tremendously in many parts of the world (Cheema 2016; Taylor et al. 2014; Venetsanou et al. 2015). Knowledge on the availability and quality of water is inevitable in groundwater development and management programs.

The quality of groundwater is mainly governed by local geology and highly influenced by environmental factors (Fitts 2002). Factors such as rainfall, temperature and $\mathrm{pH}$ conditions facilitate different subsurface physical chemical processes such as weathering, dissolution and ion exchange (Gizaw 1996). Under ideal conditions, these processes are the ones that determine groundwater chemistry and its quality as it moves across different geological formations (Kump et al. 2000; Olobaniyi and Owoyemi 2006). However, apart from natural and anthropogenic pollution sources, overabstraction has been reported worldwide as a threat to both groundwater quality and quantity (Changming et al. 2001; 
Delinom 2008; Wada et al. 2010). In order groundwater abstraction to be sustainable, a better understanding of both quantity and quality of water need to be defined by applying proper management strategies with the aid of reliable hydrogeological and hydrogeochemical data of an aquifer (Gleeson et al. 2012). This study focused on geostatistical methods for establishing groundwater quality spatial distribution in the study area. The use of geographic information system (GIS) technique has been widely adopted in proper planning and management of groundwater resource (Dixon 2005; Jha et al. 2007; Rahmati et al. 2015) due to its vast capability of effective storage, spatial analysis, and presentation of graphical outputs on water quality issues (Fenta et al. 2015; Venkatramanan et al. 2015). Hydrogeochemical data and spatial analysis help to understand the groundwater quality distribution and its suitability based on available local standards and World Health Organization's (WHO) guidelines for various uses. Such knowledge helps water resource managers and policy makers to properly plan and manage the vital resource for present and future use.

The current study was conducted in a volcanic area (southern slope of Mt. Meru) located within East African Rift System. The quality of groundwater in the rift system has been reported in previous works particularly in the Main Ethiopian Rift whereby high levels of fluoride, bicarbonate and sodium are a major concern due to high rate of carbon dioxide outgassing, acid volcanic and geothermal heating (Bretzler et al. 2011; Gizaw 1996). High fluoride levels in drinking water are a serious threat to human health specifically causing dental fluorosis and other related diseases (Moturi et al. 2002). Such natural contaminants are not uniform in groundwater systems rather are distributed depending on geological formation of a particular aquifer. This necessitates the need of undertaking hydrogeochemical investigations to determine the quality of water intended for public supplies by ensuring compliance with local and international standards. Ghiglieri et al. (2012) conducted hydrogeological and hydrochemistry study on the northeastern part of Mt. Meru in Arusha Tanzania where fluoride levels of up to $68 \mathrm{mg} / \mathrm{l}$ was observed in alkaline volcanic zones. The northern slopes of Mt. Meru are relatively dry (leeward side) compared to southern part of the mountain where the current study was carried out.

In the City of Arusha, which is situated in southern slopes of Mt. Meru, Northern Tanzania, the main source of water supply is groundwater (Mbonile 2005). The contribution of surface water (rivers) to the total amount of water abstracted is high only during rainy season. This implies that the city depends largely on groundwater as the main source of water supply for socioeconomic development. According to Arusha Urban Water Supply and Sanitation Authority (AUWSA) medium term strategic plan (2015-2020) report, groundwater contributes more than $80 \%$ of the daily water production $\left(\sim 47,000 \mathrm{~m}^{3}\right)$ supplied to the city (AUWSA 2014) with a population of about 739,640 inhabitants in accordance with 2012 population and housing census (NBS 2013). The population increase accelerates rapid growth and expansion of the city and more demand on services including potable water supply (current water demand is $93,000 \mathrm{~m}^{3} /$ day) which forces water authority to prolong water pumping from the aquifers.

Nevertheless, most deep wells in the study area were drilled and have been continuously operating for more than three decades. Previous works have noted decrease in both boreholes' yields and subsequently water levels decline in the area (Kashaigili 2010; Ong'or and Long-cang 2007; GITEC and WEMA 2011). This is attributed to rapid urbanization, industrial growth and expansion of irrigated agriculture in the area which has escalated the water supply demands (Noel et al. 2015). The problem of over-abstraction of groundwater resource has been and will keep increasing as a result of uncontrolled groundwater development in the city and all over the country (Custodio 2002; Reddy 2005). Furthermore, according to AUWSA personal communication, several boreholes have been abandoned due to increase in fluoride concentrations exceeding $10 \mathrm{mg} / \mathrm{l}$ which is beyond both Tanzanian standards $(4.0 \mathrm{mg} / \mathrm{l})$ and WHO guidelines $(1.5 \mathrm{mg} / \mathrm{l})$. Despite all these challenges, baseline and monitoring information on the trends of groundwater quality in the respective aquifers are lacking. However, pumping has been done continuously without proper understanding of the quality changes in different hydrogeological settings of the area.

Therefore, this study aimed at assessing hydrogeochemical characteristics and establishing spatial variation of groundwater quality in the City of Arusha for future groundwater management plans. The study used existing wells and springs for generating the needed information. All major cations and anions including fluoride were analyzed using conventional methods of water analysis, and the results were compared with both available local standards (Tanzania bureau of standards, TBS) and World Health Organization's (WHO) guidelines.

\section{The study area}

\section{Location}

The study was conducted in Arusha City and Arusha District, located on the southern slopes of Mount Meru in Northern Tanzania. The study area is bordered by three administrative districts of Monduli, Longido, and Meru (Fig. 1). The area covers an area of $282 \mathrm{~km}^{2}$ and lies between latitudes $3^{\circ} 15^{\prime}$ and $3^{\circ} 30^{\prime}$ South and longitudes $36^{\circ} 34^{\prime}$ and $36^{\circ} 46^{\prime}$ East (Fig. 1). According to the 2012 population and 


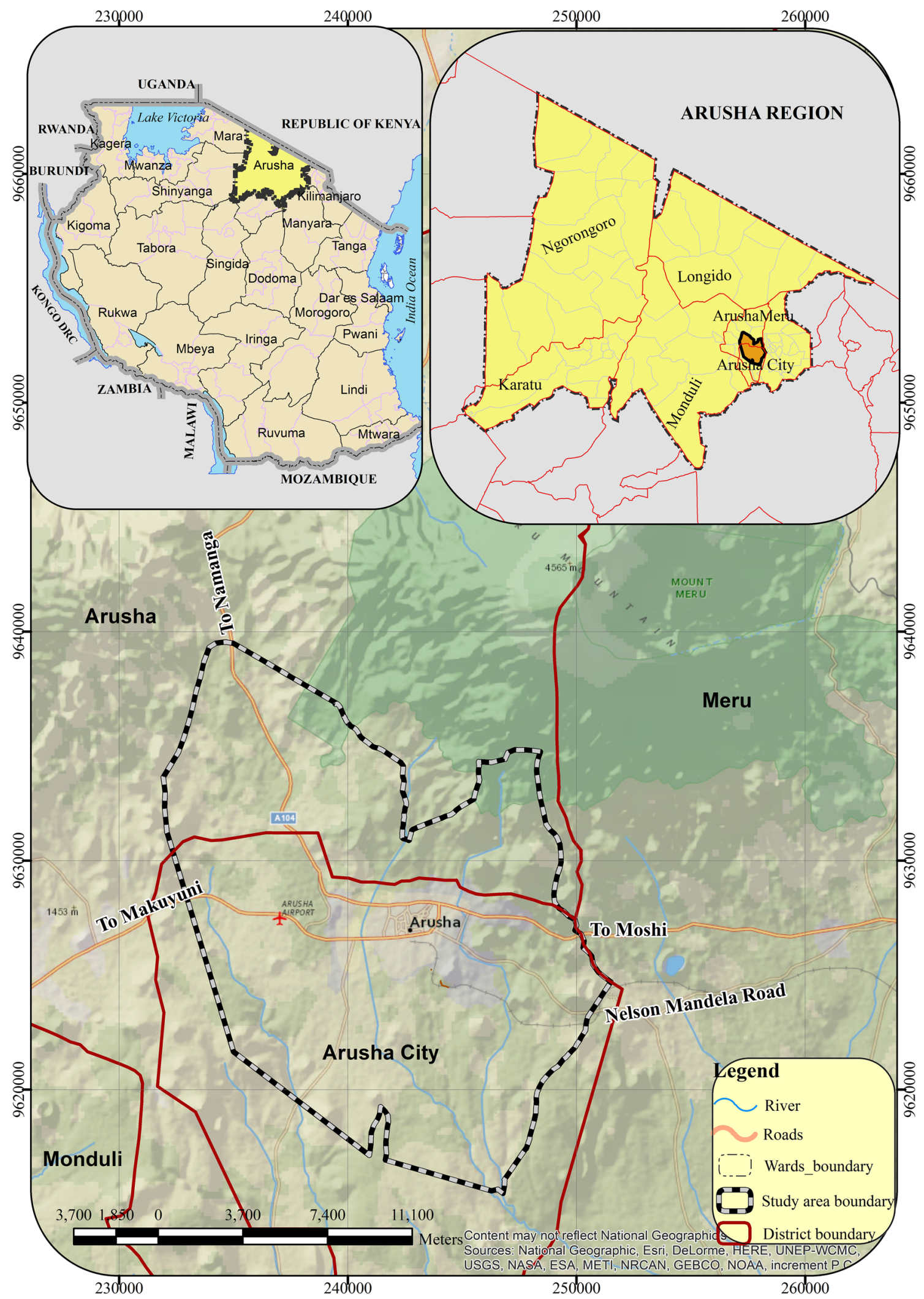

Fig. 1 Location of the study area 
housing census, the Arusha City and Arusha District had a population of 416,442 and 323,198 inhabitants, respectively (NBS 2013).

\section{Climatic characteristics}

The area is characterized by tropical climate with two distinct seasons, dry and wet seasons. The rainfall pattern in Arusha as part of northern Tanzania is bimodal with short rains from October to December and long rains from March to May (Kijazi and Reason 2009; Zorita and Tilya 2002). The annual total rainfall ranges between $500 \mathrm{~mm}$ and $1200 \mathrm{~mm}$ with mean value of about $842 \mathrm{~mm}$ (Kaihura et al. 2001). The temperature typically ranges between 13 and $30{ }^{\circ} \mathrm{C}$ with an average annual temperature of about $25^{\circ} \mathrm{C}$. The coolest month is July, whereas the warmest is February. The relative humidity varies from 55 to $75 \%$ (Anderson et al. 2012) and annual potential evapotranspiration of $924 \mathrm{~mm}$ (GITEC and WEMA 2011).

\section{Geological and hydrogeological settings}

The geology of the study area is dominated by volcanic materials of varying ages and recently deposited alluvial sediments (Ghiglieri et al. 2008, 2010; Ong'or and Longcang 2007; Wilkinson et al. 1986). Mt. Meru is the main center of volcanic activities in the region. The main features of the volcanic eruption in the area include main cone deposits, mantling ash, lahars, lava flows, pyroclastic materials, tuffs, pumice, agglomerates and volcanic rocks such basalts (Nanyaro et al. 1984; Ong'or and Long-cang 2007). Some of these volcanic features have been depicted in hydrogeologic map (Fig. 2) together with the cross section derived from hydrogeological map running from the steep slopes of Mt. Meru toward the foot of the Mountain (Fig. 3). Volcanic rocks are mainly lava flows (basaltic to phonolitic and nephelinitic tuff). These materials, if not fractured or weathered they act as aquitard which favor groundwater movement down the slope. The properties of these geological formations normally change with time due to various physical chemical reactions such as weathering and subsequent volcanic and tectonic activities. Mount Meru region is dominated by volcanic and sedimentary hydrogeologic formations with various mineralogy compositions. These include fluorapatite, natrite, halite, sylvite, aphthitalite, calcite, goethite, phillipsite, chabazite, augite, sanidine, analcime, leucite, nepheline, anorthoclase, biotite, cancrinite, riebeckite, albite and illite (Ghiglieri et al. 2012).

The area is also affected by tectonism leading to the development of fractures and faults which act as conduit to groundwater flows in some areas (Ghiglieri et al. 2010). Figure 2 shows the fault system within the main cone deposits of pyroclastic materials with subordinate nephelinitic and phonolitic lavas. The fault lines are assumed to be avenue of huge groundwater flows that manifest through numerous springs which discharge into Themi River.

Volcanic sediments and alluvium derived from different volcanic materials such as ashes, pyroclastic materials, weathered and fractured volcanic formation (e.g., basalts), phonolitic to nephelinitic formation form the major potential aquifers in the study area (Ghiglieri et al. 2010). However, mantling ash, volcanic ash and tuff, and sedimentary formations particularly fine-grained alluvial sediments are characterized by low transmissivity which become practically impermeable. In most cases such hydrogeological units act as aquitard or low yield aquifers. Groundwater recharge is mainly taking place in high elevation on the slopes of Mt. Meru along fractured formations as well as through infiltration in valleys or depression zones with medium to coarse grain sizes (Ghiglieri et al. 2010). Groundwater potentiality in fractured formation is also supported by a number of springs around the fault zone (Fig. 2), northeastern side of the study area. Springs' flows from this zone are very high particularly after or at the end of long rains. For example in May 2015 , a total of $25,698 \mathrm{~m}^{3} /$ day was abstracted from the springs by AUWSA for public water supply. This amount is only the portion of groundwater discharged from springs along this fault; the remaining water flows into Themi River which is one among the perennial and reliable water sources in the study area. Overall, most rivers and streams originate from springs located on the slopes of Mt. Meru particularly in fractured formations at high elevations. Major rivers include Themi, Kijenge, Ngarenaro, Burka and Engare Olmotonyi (Fig. 2).

Based on the hydraulic head observed from existing production wells, groundwater flows from north to south direction toward the foot of Mt. Meru. This is well supported by wells W12 and W17 with hydraulic heads at 1356 and $1348 \mathrm{~m}$ a.s.l., respectively. Thus, groundwater flows from W12 with high hydraulic head also located at elevated area to W17 with hydraulic head difference of $8 \mathrm{~m}$ at a distance of $1.2 \mathrm{~km}$. Figure 4 shows potential aquifers as derived from well logs data in the study area. The W12, W15, W16 and W9 are among the existing production wells in the area. W19 taps water from weathered or fractured basalt aquifer, whereas the rest collect water from either formation depending on the arrangement of hydrogeological units and position of the screens. This indicates that groundwater occurs both in fractured formation and volcanic sediment hosted aquifers. As mentioned before, fractured formations seem to be more productive aquifers as well as potential recharge zones in the area. Though volcanic sediment hosted aquifers cannot be ignored as they also produce substantial amount of water in the area. A good example of the well tapping water from volcanic sediment formation is W12 which discharge up to $192 \mathrm{~m}^{3} / \mathrm{h}$. However, more information are needed to 


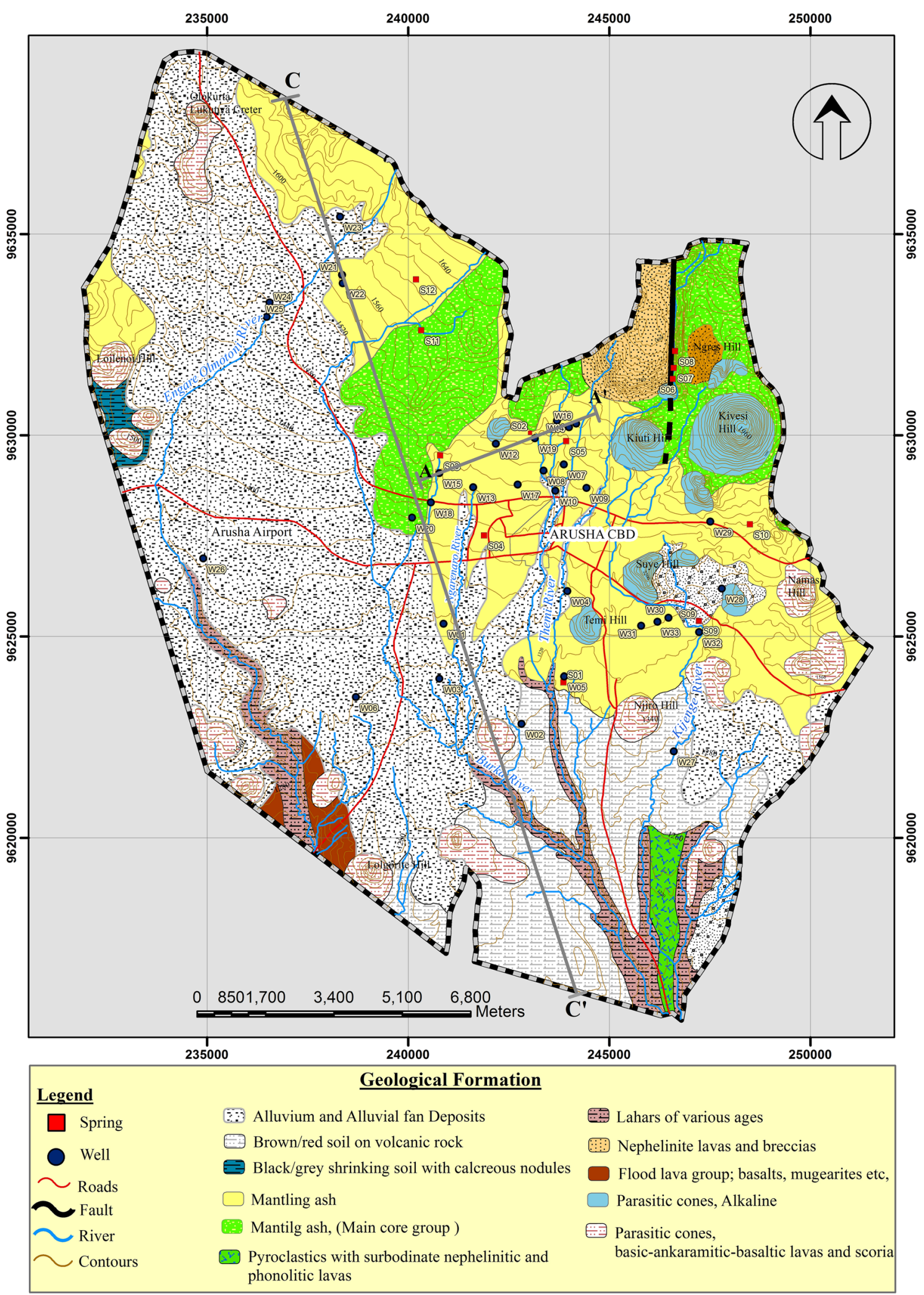

Fig. 2 Hydrogeological map showing location of sampling sites. Reproduced with permission form AA.VV. (1983) 


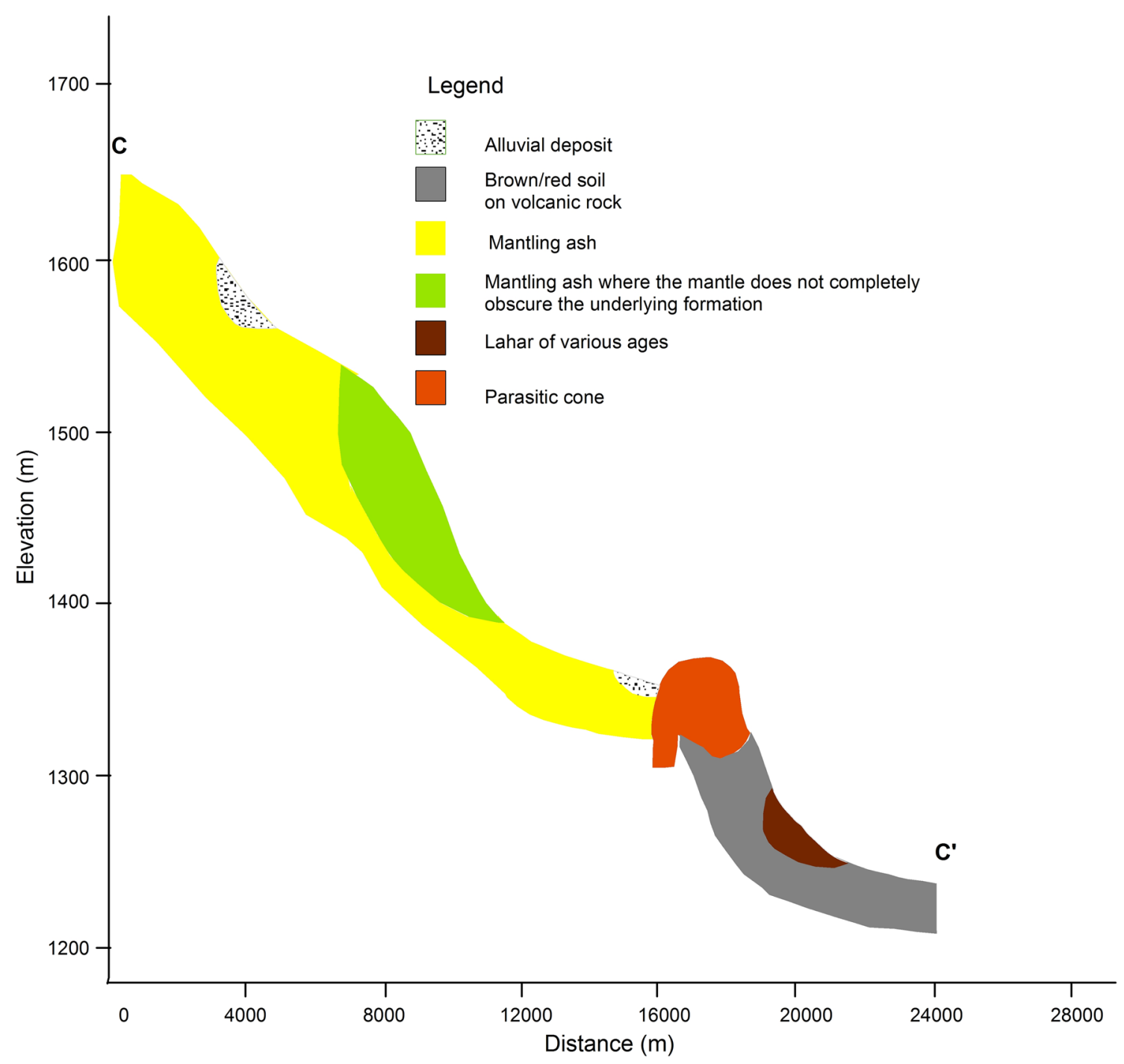

Fig. 3 Geological cross section $\mathrm{C}-\mathrm{C}^{\prime}$ from the steep slopes of Mt. Meru toward the foot of the Mountain

delineate the aquifer geometry as most wells used in this study lack hydrogeological data including well logs, depth and specific yield.

\section{Materials and methods}

\section{Field work and groundwater sampling}

Mapping and geo-referencing using a hand-held global positioning system (GPS), GARMIN GPSmap 62S was conducted to identify operational water wells and springs in the study area. A total of 46 drilled wells were identified out of which 30 deep wells $(>50 \mathrm{~m}$ ) and 3 shallow wells $(<15 \mathrm{~m})$ were used in sampling campaign together with 12 natural springs (Fig. 2). Based on available well's construction records, most wells in the study area are tapping water at different depths depending on screen positions. This suggests that majority of collected water samples represented mixed groundwater from different layers. According to the hydrogeological setting of the study area and field work, two types of springs namely fracture and depression springs were observed (Bryan 1919). Groundwater samples were collected during April and May, 2016 representing wet season in the study area.

In situ measurements of $\mathrm{pH}$, temperature, electrical conductivity (EC), total dissolved solids (TDS) and salinity were carried out using multi-parameter HANNA instrument, Model HI 9828. Equipment calibration was done prior to taking measurements according to the procedures set out by manufacturer.

Water samples were collected directly from taps located near the well heads into HDPE plastic bottles. Aliquots of samples earmarked for the analyses of sodium $\left(\mathrm{Na}^{+}\right)$, 


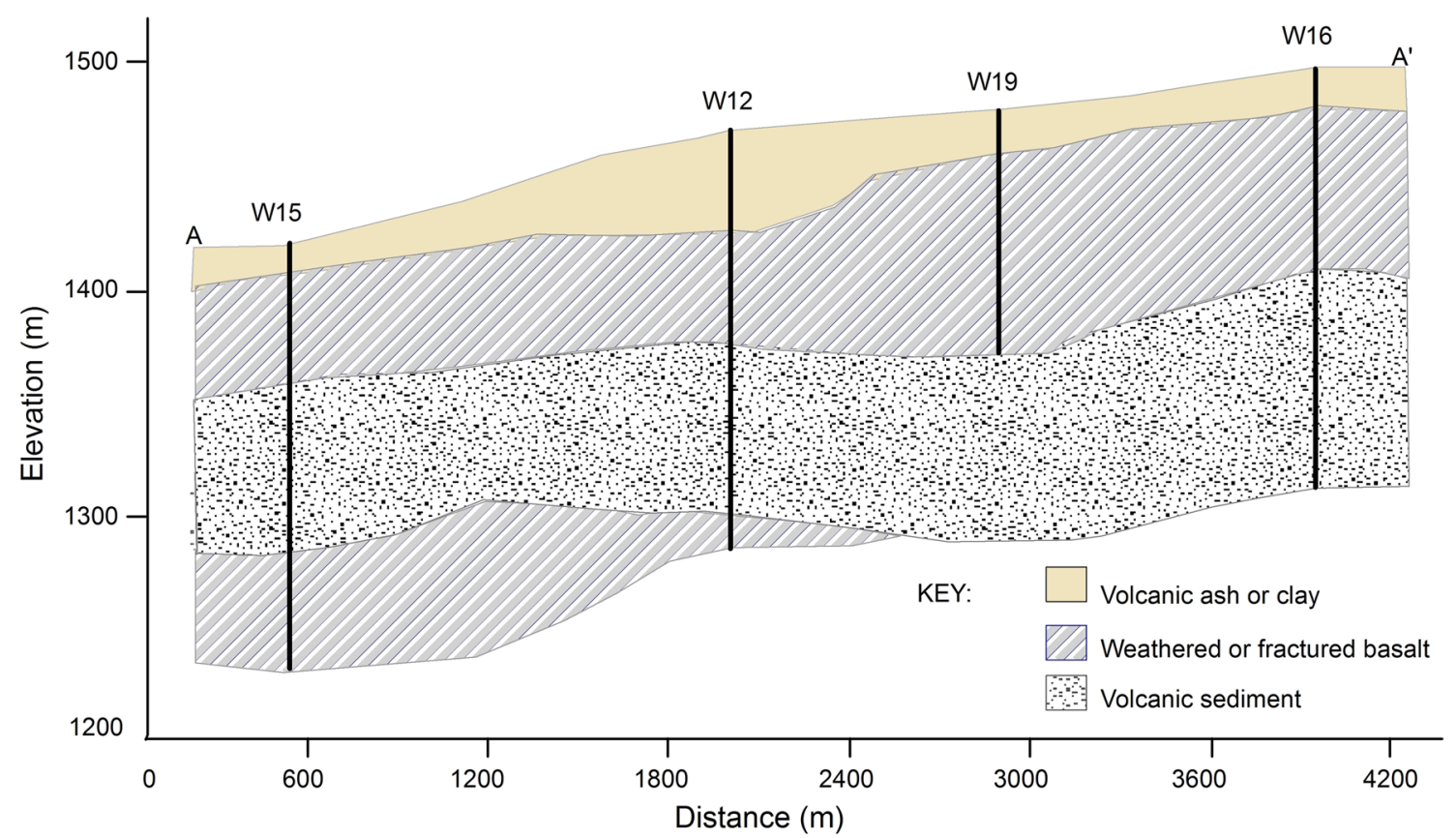

Fig. 4 Geological section A-A' derived from well logs in the study area

potassium $\left(\mathrm{K}^{+}\right)$, magnesium $\left(\mathrm{Mg}^{2+}\right)$, calcium $\left(\mathrm{Ca}^{2+}\right)$, iron $\left(\mathrm{Fe}^{2+)}\right.$ and manganese $\left(\mathrm{Mn}^{2+}\right)$ were acidified using ultrapure concentrated nitric acid, $\mathrm{HNO}_{3}$ to a $\mathrm{pH}$ less than 2.0. All samples were stored in a refrigerator at $4{ }^{\circ} \mathrm{C}$ to minimize microbial activity and any undesirable physical-chemical reaction before performing measurements of other chemical parameters including sulfate $\left(\mathrm{SO}_{4}{ }^{2-}\right)$, chloride $\left(\mathrm{Cl}^{-}\right)$, nitrate $\left(\mathrm{NO}_{3}{ }^{-}\right)$, bicarbonate $\left(\mathrm{HCO}_{3}{ }^{-}\right)$, fluoride $\left(\mathrm{F}^{-}\right)$, and phosphate $\left(\mathrm{PO}_{4}{ }^{3-}\right.$ ) (American Public Health Association 2012; Sundaram et al. 2009).

\section{Laboratory analyses}

All groundwater samples were analyzed for major cations and anions using various methods. Bicarbonate $\left(\mathrm{HCO}_{3}{ }^{-}\right)$ was determined by titration method using standard sulfuric acid and bromocresol green indicator for end point detection. The determination of $\mathrm{SO}_{4}{ }^{2-}$ (SulfaVer 4 method), $\mathrm{NO}_{3}{ }^{-}$(Cadmium reduction method), and $\mathrm{PO}_{4}{ }^{3-}$ (PhosVer 3 , Ascobic acid method) were carried out using HACH DR 2800 spectrophotometer by powder pillow test. Chloride concentration was determined by argentometric titration method using standard silver nitrate $\left(\mathrm{AgNO}_{3}\right)$ titrant and potassium chromate indicator solution (American Public Health Association 2012). Fluoride content was determined by ion selective electrode method. The fluoride concentration was read directly from the meter calibrated with standard fluoride solution before use. Fluoride buffer was prepared from glacial acetic acid, sodium chloride and 1, 2-cyclohexanediaminetetraacetic acid.

All major cations $\left(\mathrm{Na}^{+}, \mathrm{K}^{+}, \mathrm{Mg}^{2+}, \mathrm{Ca}^{2+}\right)$ and trace elements $\left(\mathrm{Fe}^{2+}\right.$ and $\left.\mathrm{Mn}^{2+}\right)$ analyses were carried out at the Ardhi University Laboratory in Dar es Salaam by Atomic absorption Spectrometer (AAS) PerkinElmer Analyst 100. Samples were filtered $(0.45 \mu \mathrm{m})$ before introduced into the flame for conversion from aerosols into atomic vapor which absorbs light from the primary source. The concentration of individual element was determined by measuring the amount of light absorbed relative to the standard solution under a specific wavelength. The accuracy of the major ions analyses was checked by calculating the charge balance error.

\section{Geostatistical analysis}

Cluster analysis, multivariate statistical analysis technique, was carried out using Paleontological Statistics (PAST) Software Package, Version 3.08 (Hammer et al. 2001). The technique was employed to understand the relationship between variables from different sampling sites and their relevance with respect to groundwater quality in the study area. The clusters were established based on similarities of variables under consideration (Davidson and Ravi 2005; Mooi and Sarstedt 2010). One-way ANOVA, single factor was used to compare means of various parameters between spring and well waters. It was also applied for comparing means of different water groups generated by cluster analysis. The correlation analysis was carried out for hydrogeochemical

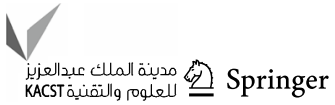


characteristics of analyzed water samples, and the significance of correlation coefficients was tested using the statistical software, SPSS version 21. A geographical Information System (GIS) Software Package, ArcGIS version 10.1, was used to generate various maps in this study. Geostatistical analysis tool was employed in establishing groundwater quality spatial variation.

\section{Piper diagram}

Piper diagram was used to graphically represent chemistry of groundwater samples in the study area (Piper 1944; Sadashivaiah et al. 2008; Srinivas et al. 2014). It comprises of three plots: a ternary diagram in the lower left representing the cations, another ternary diagram in the lower right representing the anions and a diamond plot in the middle representing a combination of the two ternary diagrams. The diagram was mainly employed to understand and identify different water composition or type through chemical relationships among groundwater samples (Utom et al. 2013).

\section{Results}

\section{Temperature, $\mathrm{pH}$, and EC}

The results of groundwater physical chemical characteristics in the study area are presented in Table 1 . The temperature for the spring water ranged from 16.7 to $22.9{ }^{\circ} \mathrm{C}$ and averaged $19.9 \pm 1.9^{\circ} \mathrm{C}$, while that of well water ranged from 19.4 to $24.5^{\circ} \mathrm{C}$ and averaged $21.9 \pm 1.1^{\circ} \mathrm{C}$. The lowest temperature in spring water was recorded at high altitude about $1600 \mathrm{~m}$ above sea level (a.s.l.) and the highest temperature at an elevation of $1322 \mathrm{~m}$ a.s.l. A slight temperature variations observed in both spring and well waters are generally influenced by different ambient conditions from low to high elevations than aquifer type. The average value of $\mathrm{pH}$ in spring and well waters was $7.2 \pm 0.7$ and $7.5 \pm 0.5$, respectively. In spring water the $\mathrm{pH}$ varied from 6.42 to 8.26 , while in well water it ranged from 6.47 to 8.9. About 42 and $15 \%$ of spring and well waters showed slightly acidic conditions ( $\mathrm{pH}$ values less than 7.0), respectively.

Electrical conductivity (EC) in well water varied from 286 to $1634 \mu \mathrm{S} / \mathrm{cm}$ with an average value of $638 \pm 330 \mu \mathrm{S} /$ $\mathrm{cm}$ which is relatively high to WHO recommended limit $(500 \mu \mathrm{S} / \mathrm{cm})$. Low EC values were detected in spring waters which ranged from 157 to $781 \mu \mathrm{S} / \mathrm{cm}$ with an average value $399 \pm 225 \mu \mathrm{S} / \mathrm{cm}$.

\section{Major cations and anions}

About $89 \%$ of the groundwater samples analyzed (Table 1) in the study area gave charge balance errors less than $\pm 10 \%$ which is acceptable in most fresh groundwater hydrogeochemical assessment (Srinivas et al. 2014; Srinivasamoorthy et al. 2008; Utom et al. 2013). The rest of the samples showed relatively high charge balance error greater than $10 \%$ which is probably due to low ionic strength (mean value $=0.0082)$ of water samples (Fritz 1994). The overall mean charge balance error was estimated to $-6.25 \%$ which is fairly reasonable for accuracy check. Figure 5 shows major ions composition of both spring and well waters in the study area. The groundwater chemistry is typically sodium-potassium Bicarbonate. The concentration of sodium $\left(\mathrm{Na}^{+}\right)$was relatively higher than other cations in all samples from spring and well waters (Table 1).

Fluoride in the study area was generally high in both spring and well waters. In well water, its concentration varied from $0.60 \mathrm{mg} / \mathrm{l}$ to $10.8 \mathrm{mg} / \mathrm{l}$ with average value of $4.04 \pm 2.39 \mathrm{mg} / \mathrm{l}$. Samples from springs were observed to have relatively low concentration ranging from 0.81 to $5.45 \mathrm{mg} / \mathrm{l}$ with mean value $2.66 \pm 1.56 \mathrm{mg} / \mathrm{l}$. Fluoride concentrations were higher than WHO guidelines $(1.5 \mathrm{mg} / \mathrm{l})$ and Tanzanian standards $(4.0 \mathrm{mg} / \mathrm{l})$ by 82 and $36 \%$ of the analyzed groundwater samples, respectively (Table 1). The concentrations of fluoride in groundwater indicated a consistent relationship with amount of $\mathrm{pH}, \mathrm{HCO}_{3}{ }^{-}, \mathrm{Ca}^{2+}$, and EC. Samples with high $\mathrm{pH}$ (alkaline condition), EC and $\mathrm{HCO}_{3}{ }^{-}$mostly in well waters were found to have high fluoride concentrations. There was a significant positive relationship between fluoride and $\mathrm{pH}, r(31)=0.62, p<0.01)$; however, the correlation between fluoride and EC $(r=0.29)$ was not statistically significant. Moreover, fluoride showed significant negative correlation with alkaline earth elements $\mathrm{Ca}^{2+}(r(31)=-0.47, p=0.006)$ and $\mathrm{Mg}^{2+}(r(31)=-0.69$, $p<0.01)$ and significant positive relationship with $\mathrm{Na}^{+}, r$ $(31)=0.426, p=0.013$ (Table 2).

In well water, nitrate concentration levels varied from 0.1 to $10.1 \mathrm{mg} / \mathrm{l}$ with average value of $2.4 \pm 2.51 \mathrm{mg} / \mathrm{l}$. Spring waters were found with relatively high nitrate levels, ranged from 1.6 to $17.3 \mathrm{mg} / \mathrm{l}$ and averaged $5.11 \pm 4.80 \mathrm{mg} / \mathrm{l}$. Only three out of forty-five analyzed groundwater samples (S04, S05 and W20) exceeded the recommended WHO drinking water limit of $10 \mathrm{mg} / \mathrm{l}$ beyond which it may cause health effects such as infant methemoglobinemia (Adelana 2005; Fan and Steinberg 1996).

The levels of both sulfate and chloride were relatively low compared to recommended WHO drinking water limit $(250 \mathrm{mg} / \mathrm{l})$. The maximum levels of sulfate detected were 43 and $69 \mathrm{mg} / \mathrm{l}$ in spring and well waters, respectively. The maximum chloride level in well water was 174 and $59 \mathrm{mg} / \mathrm{l}$ in spring water. The two constituents $\left(\mathrm{SO}_{4}{ }^{2-}\right.$ and $\mathrm{Cl}^{-}$) seemed to be related in both spring and well water samples. Figure 6 shows significant strong positive correlation between sulfate and chloride with Pearson coefficients, 


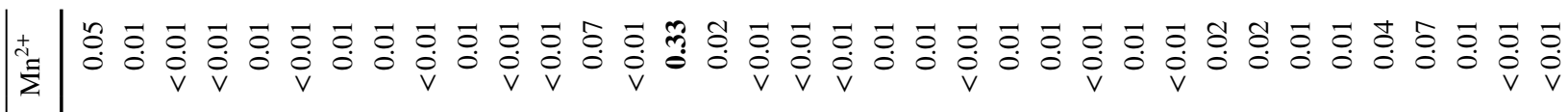
+

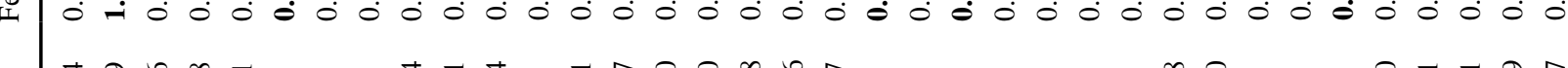

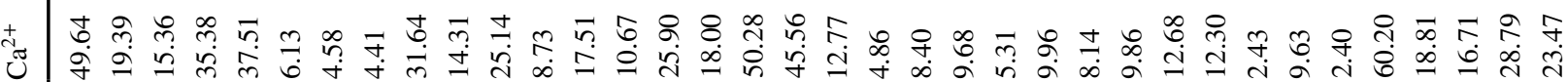

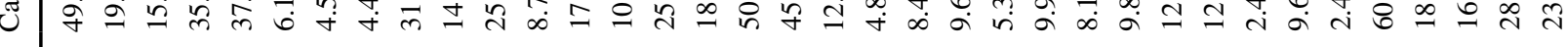

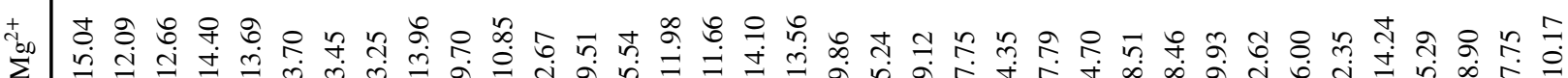

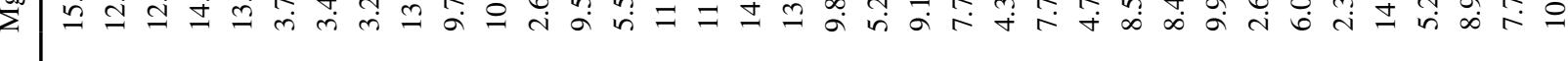

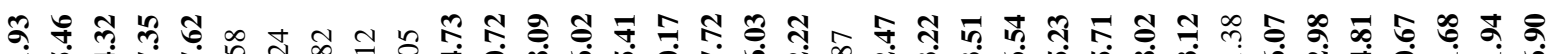
य में

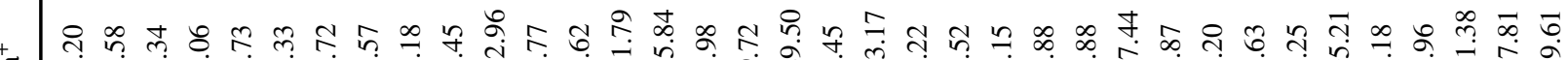

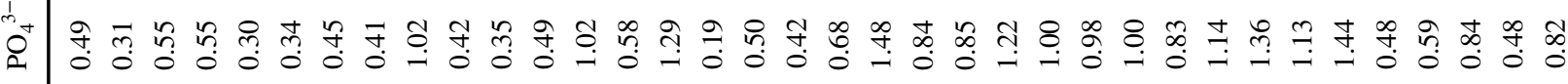

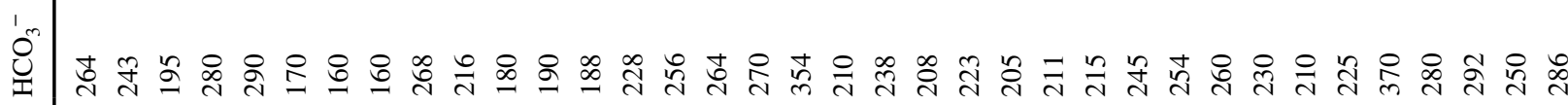
U

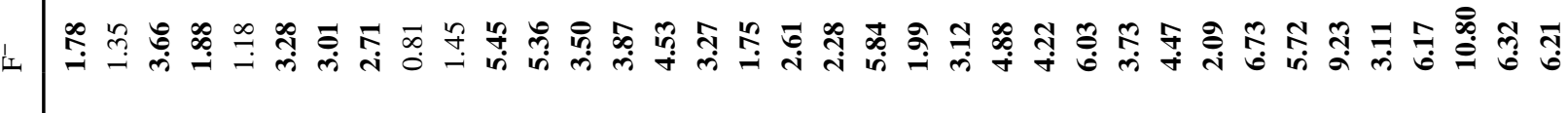

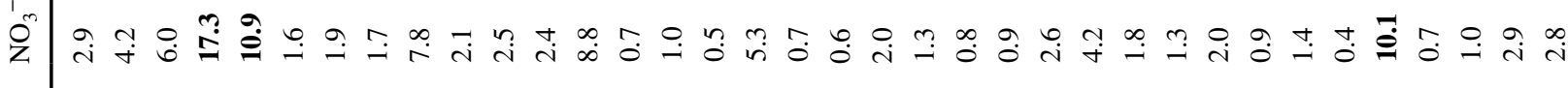
$d$
4
4

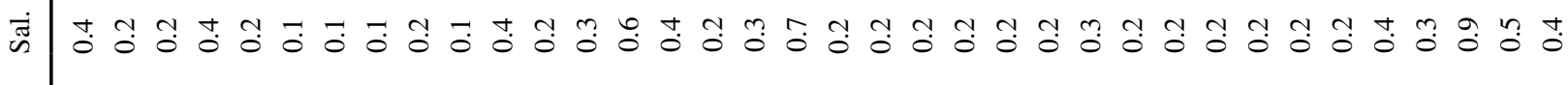

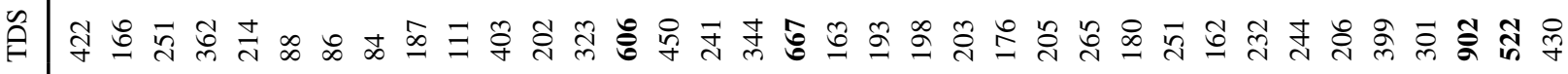

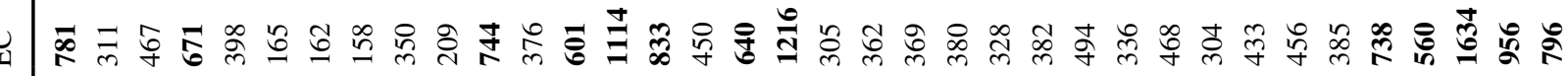

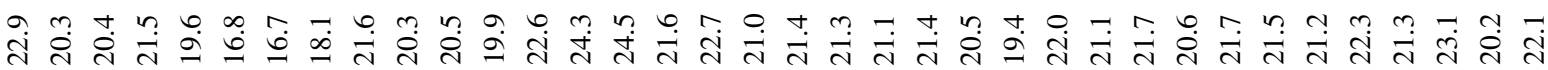

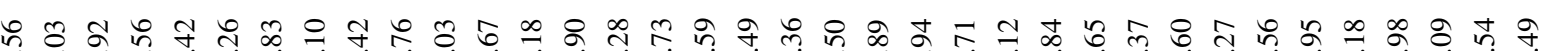

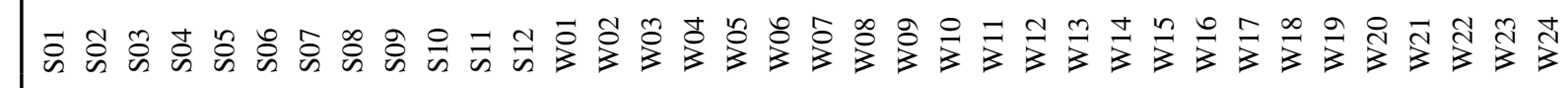




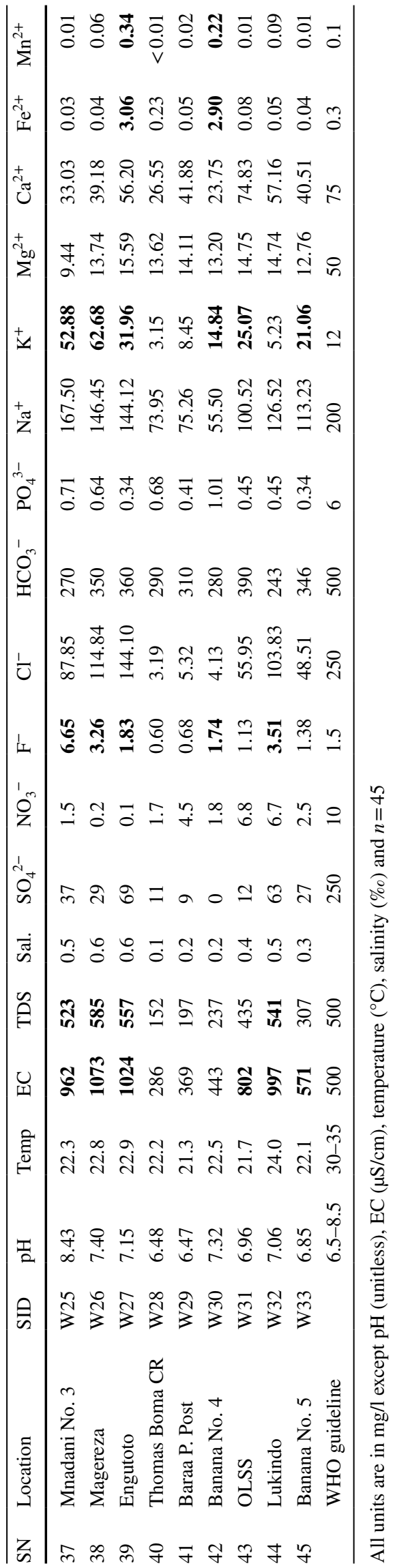

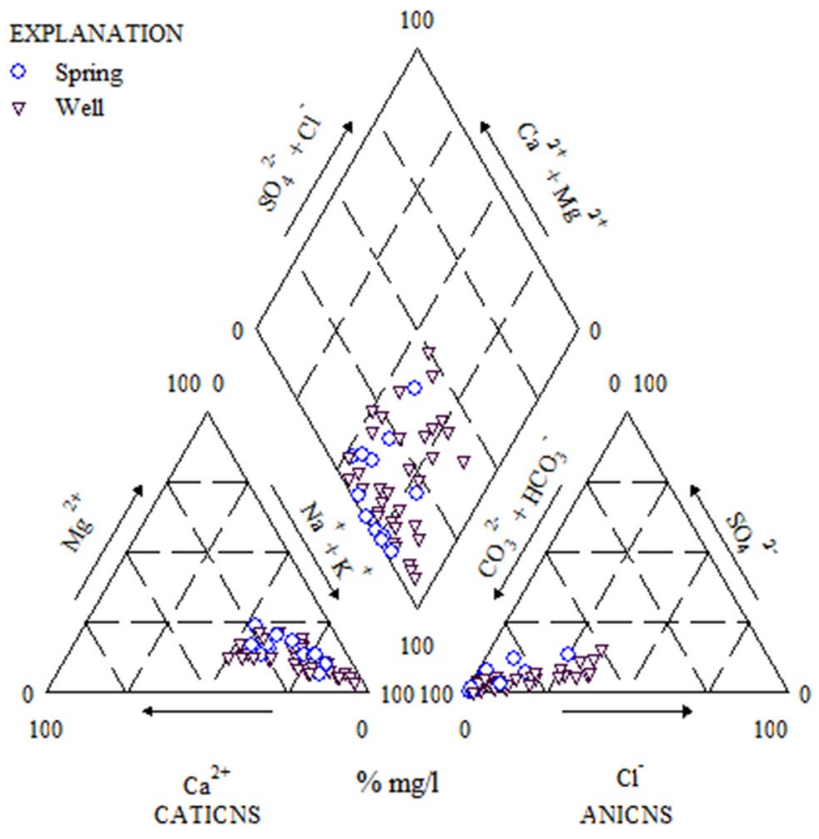

Fig. 5 Piper diagram for chemical composition of groundwater in the study area

$r(10)=0.879, p<0.01$ and $r(31)=0.858, p<00.01$ for spring and well waters, respectively.

Relatively low concentrations of dissolved phosphate were observed in most spring water and shallow wells with exception of sample S09 which recorded $1.02 \mathrm{mg} / \mathrm{l}$ (Table 1). High levels of phosphate (up to $1.48 \mathrm{mg} / \mathrm{l}$ ) were observed in deep wells ( $>100 \mathrm{~m}$ deep). The possible source of phosphate release into groundwater is apatite minerals which are common in volcanic rocks of Mt. Meru region (Roberts 2002). Figure 7 shows significant positive correlation between phosphate and well depth, $r(23)=0.547, p=0.005$. The correlation indicates that phosphate minerals are more pronounced in deep geological formation of the study area.

\section{Trace elements (Fe and Mn)}

Iron concentration varied from 0.02 to $3.06 \mathrm{mg} / \mathrm{l}$ (well water) and 0.03 to $1.93 \mathrm{mg} / \mathrm{l}$ (spring water). More than $84 \%$ of the analyzed water samples had $\mathrm{Fe}$ contents less than recommended maximum WHO limit $(0.3 \mathrm{mg} / \mathrm{l})$. Furthermore, the concentration of manganese was generally very low. About $36 \%$ of analyzed water samples were below the detection limits $(0.01 \mathrm{mg} / \mathrm{l})$. However, only two samples (W03 and W27) out of forty-five were observed to have manganese levels beyond the recommended WHO guideline $(0.1 \mathrm{mg} / \mathrm{l})$. Generally, the levels of iron and manganese detected in this study were relatively low which have no significant health effect or engineering problems in water supply infrastructures. 
Table 2 Pearson correlation matrix for samples from well water

\begin{tabular}{|c|c|c|c|c|c|c|c|c|c|c|c|c|c|c|c|}
\hline & $\mathrm{pH}$ & Temp & $\mathrm{EC}$ & TDS & Sal. & $\mathrm{SO}_{4}^{2-}$ & $\mathrm{NO}_{3}{ }^{-}$ & $\overline{F^{-}}$ & $\mathrm{Cl}^{-}$ & $\mathrm{HCO}_{3}^{-}$ & $\mathrm{PO}_{4}^{3-}$ & $\mathrm{Na}^{+}$ & $\mathrm{K}^{+}$ & $\mathrm{Mg}^{2+}$ & $\mathrm{Ca}^{2+}$ \\
\hline $\mathrm{pH}$ & 1 & & & & & & & & & & & & & & \\
\hline Temp & 0.04 & 1 & & & & & & & & & & & & & \\
\hline EC & 0.21 & 0.53 & 1 & & & & & & & & & & & & \\
\hline TDS & 0.21 & 0.53 & 1.00 & 1 & & & & & & & & & & & \\
\hline Sal. & 0.24 & 0.47 & 0.99 & 0.99 & 1 & & & & & & & & & & \\
\hline $\mathrm{SO}_{4}{ }^{2-}$ & -0.10 & 0.40 & 0.76 & 0.76 & 0.75 & 1 & & & & & & & & & \\
\hline $\mathrm{NO}_{3}{ }^{-}$ & -0.45 & 0.14 & 0.03 & 0.03 & -0.01 & 0.08 & 1 & & & & & & & & \\
\hline $\mathrm{F}^{-}$ & 0.62 & -0.02 & 0.29 & 0.30 & 0.29 & 0.07 & -0.24 & 1 & & & & & & & \\
\hline $\mathrm{Cl}^{-}$ & 0.11 & 0.51 & 0.97 & 0.97 & 0.97 & 0.84 & -0.04 & 0.18 & 1 & & & & & & \\
\hline $\mathrm{HCO}_{3}^{-}$ & -0.38 & 0.19 & 0.45 & 0.45 & 0.45 & 0.44 & 0.17 & -0.34 & 0.49 & 1 & & & & & \\
\hline $\mathrm{PO}_{4}{ }^{3-}$ & 0.30 & -0.17 & -0.39 & -0.39 & -0.38 & -0.51 & -0.21 & 0.48 & -0.43 & -0.60 & 1 & & & & \\
\hline $\mathrm{Na}^{+}$ & 0.24 & 0.37 & 0.90 & 0.90 & 0.90 & 0.70 & -0.10 & 0.43 & 0.89 & 0.44 & -0.26 & 1 & & & \\
\hline $\mathrm{K}^{+}$ & 0.23 & 0.18 & 0.83 & 0.83 & 0.84 & 0.54 & -0.07 & 0.36 & 0.78 & 0.44 & -0.31 & 0.81 & 1 & & \\
\hline $\mathrm{Mg}^{2+}$ & -0.69 & 0.35 & 0.30 & 0.30 & 0.28 & 0.45 & 0.36 & -0.69 & 0.39 & 0.70 & -0.67 & 0.17 & 0.19 & 1 & \\
\hline $\mathrm{Ca}^{2+}$ & -0.55 & 0.33 & 0.46 & 0.45 & 0.43 & 0.61 & 0.52 & -0.47 & 0.50 & 0.81 & -0.70 & 0.31 & 0.30 & 0.84 & 1 \\
\hline
\end{tabular}

Green color indicates negative correlation $(r<-0.5)$ and pink color, positive correlation $(r>0.5)$

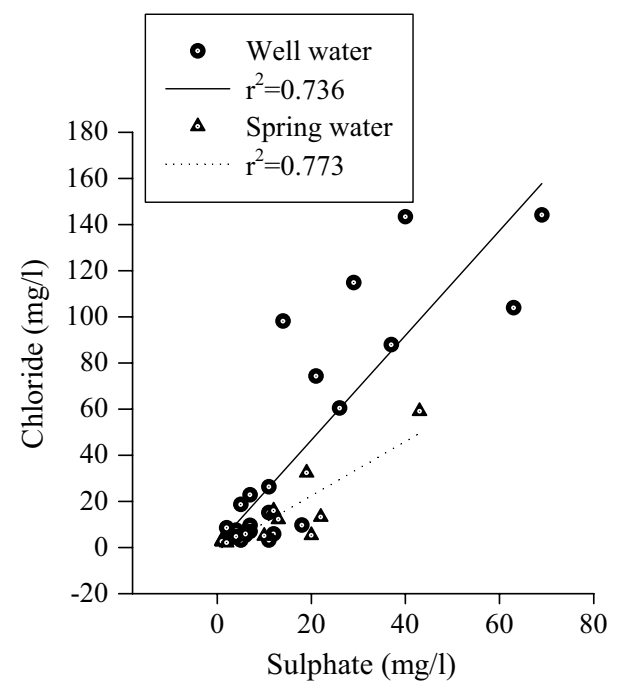

Fig. 6 Scatter plot for sulfate and chloride

\section{Multivariate analysis}

Analyzed water samples were grouped into four main categories, the first group comprises of cluster A and B with a total of fourteen samples which indicated great than $60 \%$ similarity. Six out of fourteen in this group being samples from spring water. Cluster $\mathrm{C}$ has a total of six (6) sampling sites all being wells. The third group (Cluster D) has twelve (12) sampling sites with great than $60 \%$ similarity and one of its sub-clusters has greater than $90 \%$ similarity index. The last group (Cluster

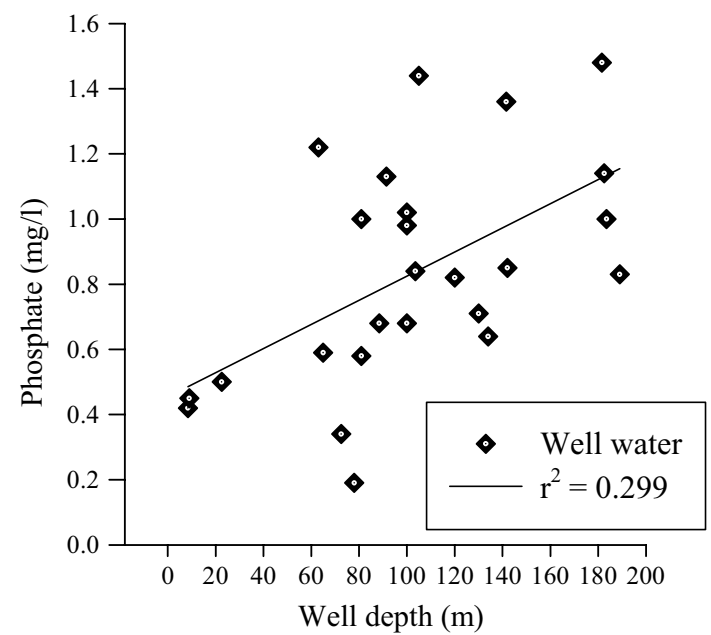

Fig. 7 Phosphate variations with well depth

E) comprises of four (4) sampling sites (springs) with great than $95 \%$ similarity. However, out of 45 sampling sites, five showed less than $50 \%$ similarity with other clusters (Fig. 8).

\section{Discussion}

\section{Groundwater chemistry}

The results of major ions for groundwater plotted in piper diagram (Fig. 5) indicated both spring and well waters 


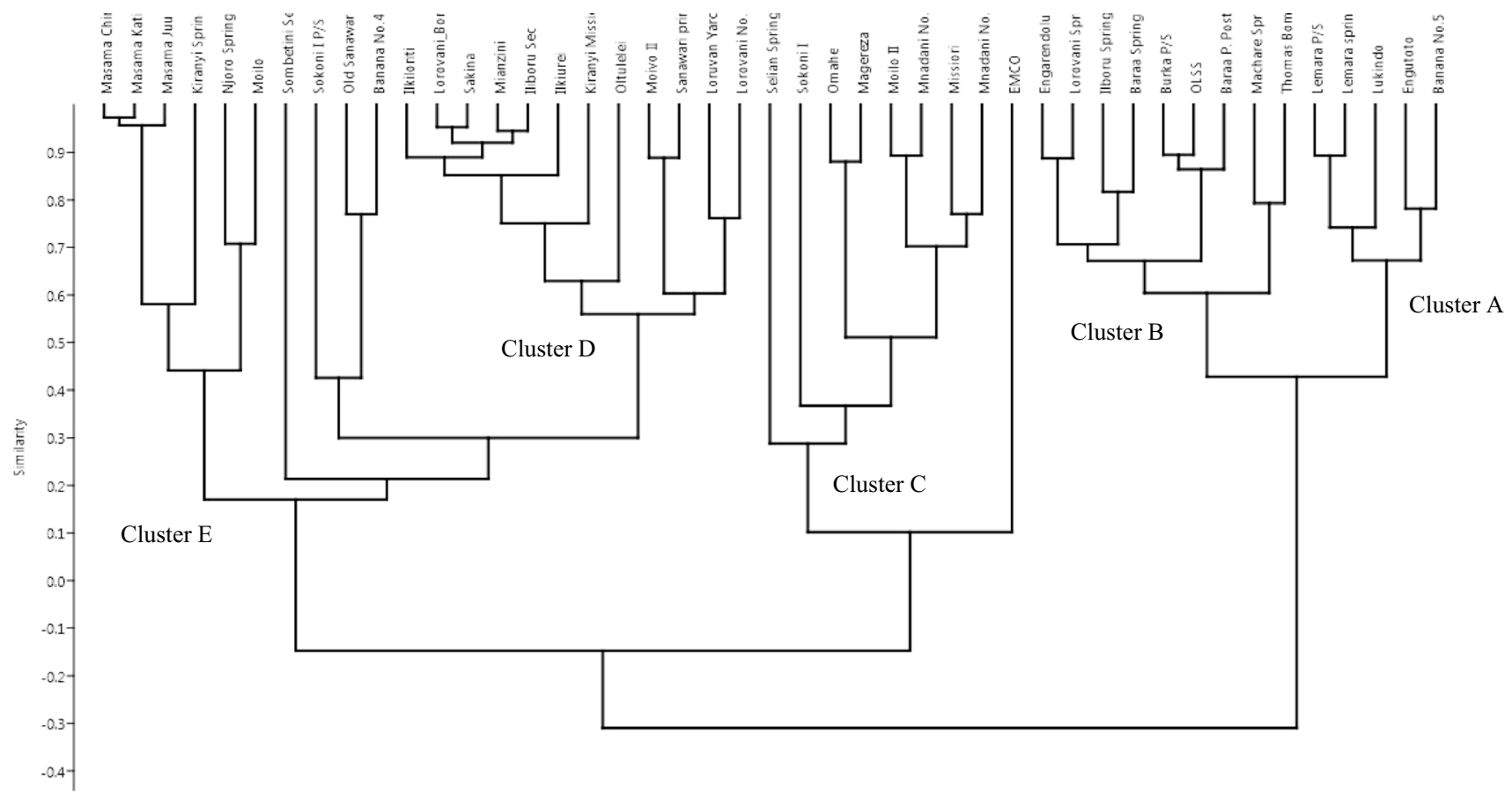

Fig. 8 Dendrogram for groundwater hydrogeochemical data from 45 sampling sites

to fall under sodium-potassium bicarbonate water type. The chemical properties of groundwater are dominated by alkali elements $\left(\mathrm{Na}^{+}\right.$and $\left.\mathrm{K}^{+}\right)$and weak acids $\left(\mathrm{HCO}_{3}{ }^{-}\right)$. Sodium ion was generally dominant in all samples with
Magnesium being the least cation in the study area $\left(\mathrm{Na}^{+}>\mathrm{Ca}^{2+}>\mathrm{K}^{+}>\mathrm{Mg}^{2+}\right)$. Such chemical behavior in groundwater is explained by cations exchange reactions between $\mathrm{Na}^{+}$and $\mathrm{Ca}^{2+}$ which occur as a result of

Table 3 Pearson correlation matrix for samples from spring water

\begin{tabular}{|c|c|c|c|c|c|c|c|c|c|c|c|c|c|c|c|}
\hline & $\mathrm{pH}$ & Temp & $\mathrm{EC}$ & TDS & Sal. & $\mathrm{SO}_{4}{ }^{2-}$ & $\mathrm{NO}_{3}{ }^{-}$ & $\mathrm{F}^{-}$ & $\mathrm{Cl}^{-}$ & $\mathrm{HCO}_{3}^{-}$ & $\mathrm{PO}_{4}{ }^{3-}$ & $\mathrm{Na}^{+}$ & $\mathrm{K}^{+}$ & $\mathrm{Mg}^{2+}$ & $\mathrm{Ca}^{2+}$ \\
\hline $\mathrm{pH}$ & 1 & & & & & & & & & & & & & & \\
\hline Temp & -0.76 & 1 & & & & & & & & & & & & & \\
\hline $\mathrm{EC}$ & -0.53 & 0.76 & 1 & & & & & & & & & & & & \\
\hline TDS & -0.53 & 0.76 & 1.00 & 1 & & & & & & & & & & & \\
\hline Sal. & -0.55 & 0.74 & 0.98 & 0.98 & 1 & & & & & & & & & & \\
\hline $\mathrm{SO}_{4}^{2-}$ & -0.61 & 0.74 & 0.88 & 0.88 & 0.84 & 1 & & & & & & & & & \\
\hline $\mathrm{NO}_{3}^{-}$ & -0.56 & 0.41 & 0.39 & 0.39 & 0.44 & 0.32 & 1 & & & & & & & & \\
\hline $\mathrm{F}^{-}$ & 0.57 & -0.27 & 0.16 & 0.16 & 0.12 & -0.17 & -0.41 & 1 & & & & & & & \\
\hline $\mathrm{Cl}^{-}$ & -0.50 & 0.72 & 0.78 & 0.78 & 0.77 & 0.88 & 0.30 & -0.23 & 1 & & & & & & \\
\hline $\mathrm{HCO}_{3}{ }^{-}$ & -0.88 & 0.71 & 0.46 & 0.45 & 0.48 & 0.60 & 0.74 & -0.69 & 0.52 & 1 & & & & & \\
\hline $\mathrm{PO}_{4}^{3-}$ & -0.29 & 0.41 & 0.08 & 0.08 & 0.08 & 0.07 & 0.27 & -0.26 & 0.25 & 0.29 & 1 & & & & \\
\hline $\mathrm{Na}^{+}$ & -0.41 & 0.54 & 0.84 & 0.84 & 0.80 & 0.66 & 0.22 & 0.34 & 0.44 & 0.19 & 0.11 & 1 & & & \\
\hline $\mathrm{K}^{+}$ & -0.31 & 0.56 & 0.71 & 0.71 & 0.71 & 0.53 & 0.70 & 0.07 & 0.54 & 0.48 & 0.00 & 0.37 & 1 & & \\
\hline $\mathrm{Mg}^{2+}$ & -0.81 & 0.82 & 0.66 & 0.66 & 0.64 & 0.75 & 0.61 & -0.52 & 0.61 & 0.84 & 0.29 & 0.52 & 0.50 & 1 & \\
\hline $\mathrm{Ca}^{2+}$ & -0.85 & 0.81 & 0.77 & 0.77 & 0.76 & 0.91 & 0.56 & -0.44 & 0.80 & 0.86 & 0.24 & 0.55 & 0.51 & 0.87 & 1 \\
\hline
\end{tabular}

Green color indicates negative correlation $(r<-0.5)$ and pink color, positive correlation $(r>0.5)$ 
Table 4 One-way ANOVA, single-factor results comparing spring and well waters

\begin{tabular}{lllll}
\hline Ion/parameter & $d f$ & $F$ & $p$ value & Sig. level, $\alpha$ \\
\hline $\mathrm{pH}$ & $1^{\mathrm{a}}, 43^{\mathrm{b}}$ & 2.06 & $\mathbf{0 . 1 5 9}$ & 0.05 \\
$\mathrm{EC}$ & $1^{\mathrm{a}}, 43^{\mathrm{b}}$ & 5.34 & 0.026 & 0.05 \\
$\mathrm{HCO}_{3}{ }^{-}$ & $1^{\mathrm{a}}, 43^{\mathrm{b}}$ & 7.58 & 0.009 & 0.01 \\
$\mathrm{~F}^{-}$ & $1^{\mathrm{a}}, 41^{\mathrm{b}}$ & 6.09 & 0.018 & 0.05 \\
$\mathrm{Na}^{+}$ & $1^{\mathrm{a}}, 43^{\mathrm{b}}$ & 5.78 & 0.021 & 0.05 \\
$\mathrm{NO}_{3}^{-}$ & $1^{\mathrm{a}}, 43^{\mathrm{b}}$ & 5.93 & 0.019 & 0.05 \\
\hline
\end{tabular}

${ }^{a}$ Degree of freedom between groups

${ }^{b}$ degree of freedom within groups

Fig. 9 Comparison of means of selected major ions in spring and well waters water-rock interaction as water moves through different mineralogical composition (Cerling et al. 1989; Ghiglieri et al. 2012; Utom et al. 2013). The ions distribution (Fig. 5) and significant positive correlation (Table 2) between bicarbonate ion and major cations, $\mathrm{Ca}^{2+}(r$ $(31)=0.81, p<0.01), \mathrm{Mg}^{2+}(r(31)=0.70, p<0.01), \mathrm{Na}^{+}(r$ $(31)=0.44, p=0.011)$ and $\mathrm{K}^{+}(r(31)=0.44, p=0.010)$, in well water indicate that these constituents are naturally occurring through weathering and water-rock interaction mechanisms (Ishaku et al. 2015; Srinivasamoorthy et al. 2012). The same trend of positive correlation was also observed in spring water (Table 3). From other literature it is also suggested that in geothermal system, most of
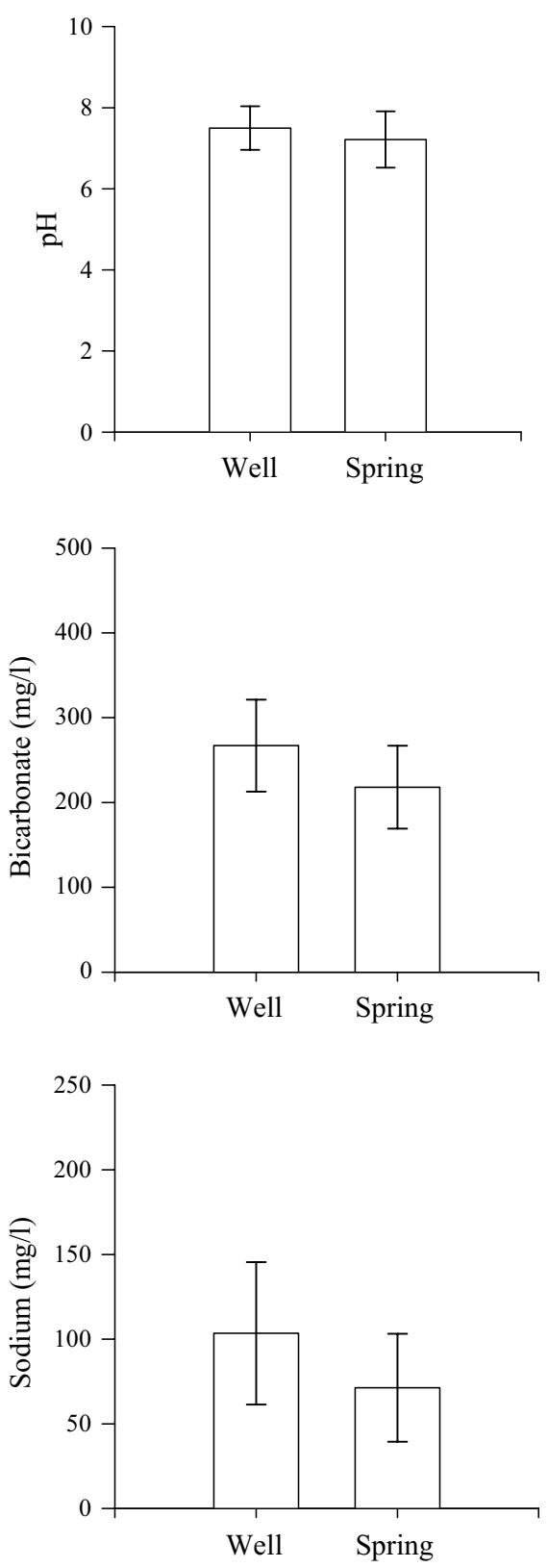
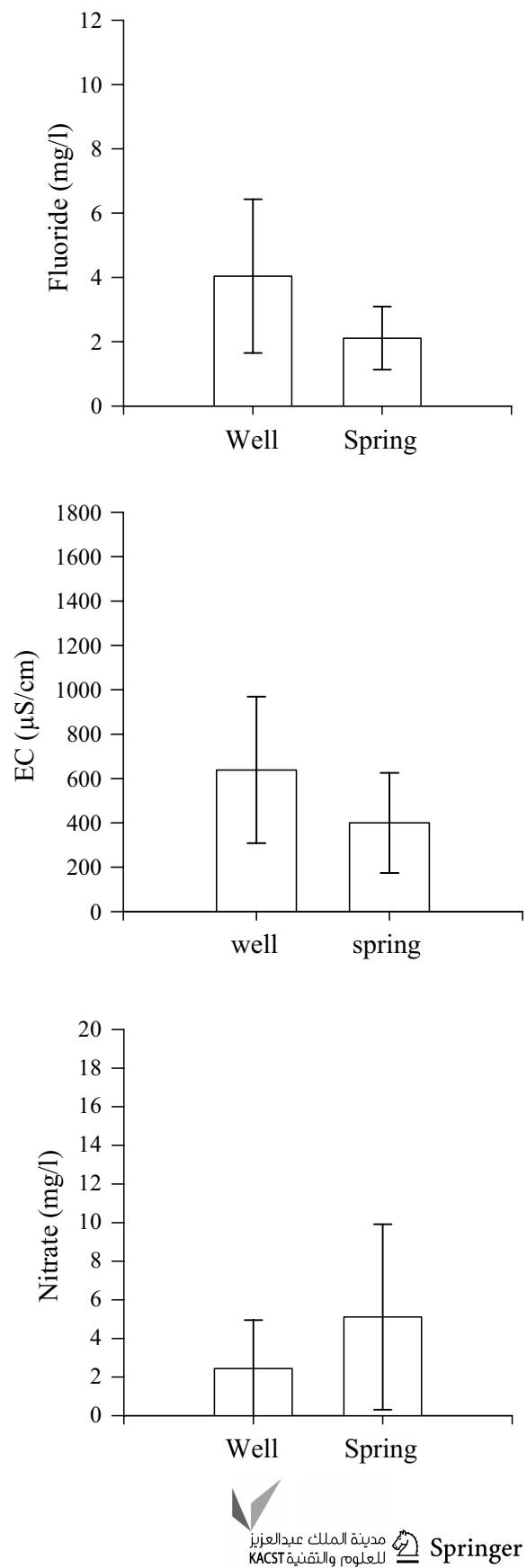
$\mathrm{HCO}_{3}{ }^{-}$and part of alkali elements are produced by the reactions of dissolved carbon dioxide $\left(\mathrm{CO}_{2}\right)$ with rocks (Gizaw 1996). Generally, both well and spring waters in the study area were characterized by same water type $\left(\mathrm{Na}-\mathrm{K}-\mathrm{HCO}_{3}\right)$ as presented in the piper diagram. However, spring water contains significantly less dissolved ions (Table 4) compared to well water (Fig. 9). Based on field observation most springs are originating from aquifers which are highly influenced by rainfall. Their discharges increase significantly during or immediately after rainy season i.e., water-rock interaction time is relatively short hence less dissolved ions. The hydrochemistry of groundwater in the study area particularly deep wells is mainly controlled by geochemical reactions and natural processes than anthropogenic influences. The water type $\left(\mathrm{Na}-\mathrm{K}-\mathrm{HCO}_{3}\right)$ and distribution of major cations and anions in the piper diagram indicate that groundwater hydrochemistry is mainly influenced by aquifer lithology. As to a large extent the hydrogeological formation of the region is characterized by the presence of sodium- and
Fig. 10 Comparison of means of selected major ions for different water clusters
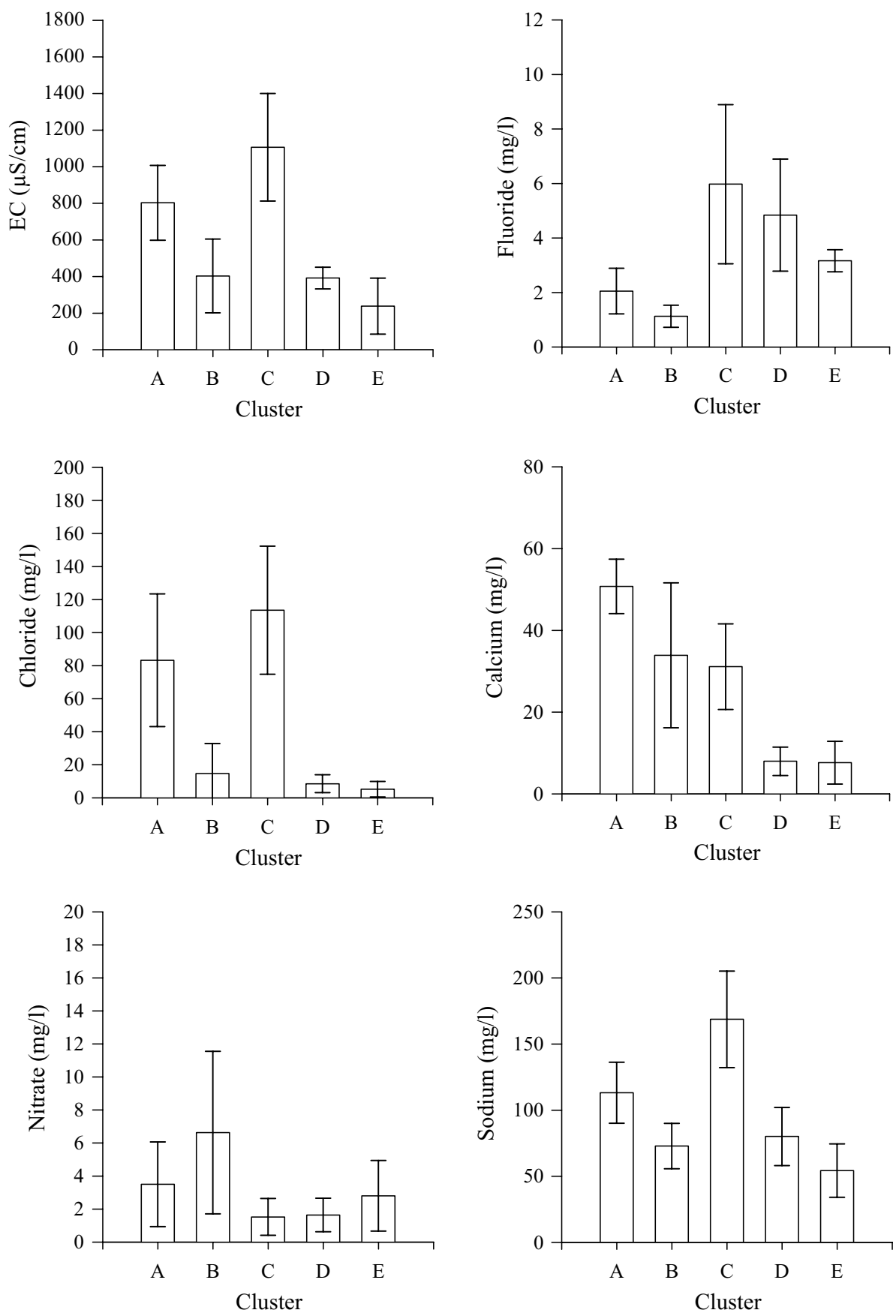

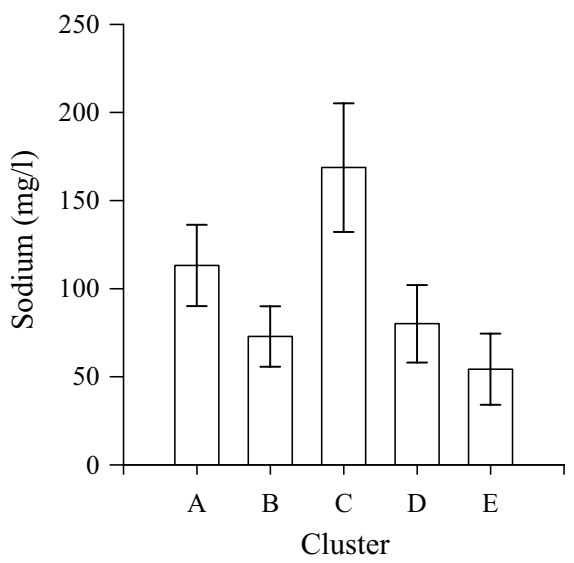


Table 5 One-way ANOVA, single-factor results comparing water clusters

\begin{tabular}{llcll}
\hline Ion/parameter & $d f$ & $F$ & $p$ value & Sig. level, $\alpha$ \\
\hline $\mathrm{EC}$ & $4^{\mathrm{a}}, 31^{\mathrm{b}}$ & 22.98469 & $6.7 \mathrm{E}-09$ & 0.01 \\
$\mathrm{Na}^{+}$ & $4^{\mathrm{a}}, 31^{\mathrm{b}}$ & 21.06345 & $1.8 \mathrm{E}-08$ & 0.01 \\
$\mathrm{Ca}^{2+}$ & $4^{\mathrm{a}}, 31^{\mathrm{b}}$ & 19.99604 & $3.2 \mathrm{E}-08$ & 0.01 \\
$\mathrm{~F}^{-}$ & $4^{\mathrm{a}}, 31^{\mathrm{b}}$ & 9.916838 & $2.8 \mathrm{E}-05$ & 0.01 \\
$\mathrm{Cl}^{-}$ & $4^{\mathrm{a}}, 31^{\mathrm{b}}$ & 29.21781 & $4 \mathrm{E}-10$ & 0.01 \\
$\mathrm{NO}_{3}^{-}$ & $4^{\mathrm{a}}, 31^{\mathrm{b}}$ & 4.717767 & 0.004 & 0.01 \\
\hline
\end{tabular}

${ }^{a}$ Degree of freedom between groups

${ }^{b}$ degree of freedom within groups

potassium-rich minerals such as nepheline, chabazite, sanidine, cancrinite, phillipsite and anorthoclase (Ghiglieri et al. 2012). Generally, sodium and potassium ions were relatively high in all groundwater samples (Table 1) indicating the influence of water-rock interaction in determining groundwater chemistry of the study area. This is also supported by low levels of anthropogenic indicators such as nitrate, chloride and sulfate observed in deep wells (Table 1). Moreover, statistical error bars of selected major ions were plotted to compare water clusters (Fig. 10). A slight difference between clusters was observed from the error bar plots. Additionally, the results of statistical test using one-way ANOVA, single factor indicated a significance difference between clusters for the selected major ions (Table 5). The differences shown between clusters are probably due to heterogeneity of the volcanic aquifers in the study area (Ong'or and Long-cang 2007). However, the groundwater hydrochemistry of the study area remains the same with $\mathrm{Na}-\mathrm{K}-\mathrm{HCO}_{3}$ water type.

\section{Fluoride}

Fluoride concentration in the study area was generally high in both spring and well waters. Its concentrations varied from one location to another indicating different mineralogy or geological formation which may have different dissolution rate, cation exchange capacity and precipitation in the aquifer matrix (Ghiglieri et al. 2012). Fluoride concentration indicated positive correlation with $\mathrm{Na}^{+}$and negative correlation with alkaline earth elements $\left(\mathrm{Ca}^{2+}\right.$ and $\left.\mathrm{Mg}^{2+}\right)$ (Table 2). This association indicates that during ionic exchange process and precipitation when calcium ion is removed from groundwater system more $\mathrm{Na}^{+}$and $\mathrm{F}^{-}$ions are being released from minerals such as fluorapatite and nepheline in the aquifer matrix. Similar findings on fluoride behavior with alkaline earth elements $\left(\mathrm{Ca}^{2+}, \mathrm{Mg}^{2+}\right)$ and alkali metals $\left(\mathrm{Na}^{+}, \mathrm{K}^{+}\right)$are well documented (Chae et al. 2007; Guo et al. 2012; Rafique et al. 2009). Moreover, Ghiglieri et al. (2012) and Srinivasamoorthy et al. (2012) revealed that alkaline nature of groundwater enhances fluoride releases from fluorine-rich minerals such as fluorite $\left(\mathrm{CaF}_{2}\right)$ into water system. Furthermore, according to the batch experiments conducted (Saxena and Ahmed 2001) at normal room temperature fluoride is easily released from parent rocks at a $\mathrm{pH}, \mathrm{EC}$ and $\mathrm{HCO}_{3}{ }^{-}$range of 7.6-8.6, 750-1750 $\mu \mathrm{S} / \mathrm{cm}$ and $350-450 \mathrm{mg} / \mathrm{l}$, respectively. These findings are in line with high fluoride concentrations detected in groundwater samples with high bicarbonate and $\mathrm{pH}$ values. In addition, water-rock interaction influences the concentration and rate of fluoride release into groundwater system. Low fluoride concentration in fractured and highly permeable phonolite hosted aquifers has been reported, and high fluoride concentration in water originating from basalt and lahars formation (Ghiglieri et al. 2010). This suggests that variations of fluoride concentrations in groundwater are mainly controlled by both aquifer materials and mean residence time. The geological-hydrogeological section $\mathrm{A}-\mathrm{A}^{\prime}$ (Fig. 4) constructed from well logs indicates that most wells collect water from volcanic sediment aquifers except W19 which is located in weathered and/or fractured basalt formation. W19 indicated high fluoride concentration $(9.23 \mathrm{mg} / \mathrm{l})$ compared to wells W12 (4.2 mg/l) and W16 (2.09 mg/l) which tap water from volcanic sediment aquifer. However, it should be noted that groundwater samples were collected from different depths within a single well depending on the position of the screens (Table 6).

In the study area the spatial distribution of fluoride concentrations indicates high fluoride concentration in northern and northwestern parts of the study area (Fig. 11).
Table 6 Well construction details indicating position of the screens

\begin{tabular}{llll}
\hline Well ID & Depth $(\mathrm{m})$ & Screen position (m below ground surface) & $\begin{array}{l}\text { Aquifer thickness } \\
\text { covered by screens } \\
(\mathrm{m})\end{array}$ \\
\hline W10 & 142 & $44-52,64-76,80-124,132-136$ & 92 \\
W12 & 184 & $80-100,120-156,162-176$ & 96 \\
W16 & 183 & $80-88,100-108,112-128,136-168$ & 88 \\
W19 & 108 & $28-48,64-70,76-84,88-96$ & 68 \\
W17 & 142 & $56-64,72-120,124-136$ & 80 \\
\hline
\end{tabular}

The data were compiled from well logs and construction details compiled from drilling companies 
High fluoride concentration in this zone is probably due to dominance in basalt formation and other fluoride-rich volcanic materials such as lahars and volcanic ash (Figs. 3, 4) which are known to contain and release significant amount of fluoride into groundwater in the region (Ghiglieri et al. 2012). It is unfortunate that the northwestern part is one of the areas earmarked by water authority to have potential groundwater reserve for present and future use. It should be noted that groundwater reserve in this part is obviously reduced as its quality won't satisfy the intended use (Ako et al. 2011; Currell et al. 2012). However, the southern part of the study area shows relatively low levels of fluoride concentration compared to north and therefore calls for further groundwater exploration for future development.

\section{Spatial distributions of nitrate, sulfate and chloride}

Nitrate and other nutrients are among the best indicators of anthropogenic influence in groundwater quality assessment (Kaown et al. 2009). Apart from on-site sanitation practice in the research area, urban agriculture and animal husbandry are also common. All these are likely to threaten the quality of groundwater for various uses including drinking and other domestic purposes. The chances of pollutants to be released and transported from these anthropogenic sources to the shallow aquifers are very high (Drechsel and Dongus 2010). Very low concentrations of nitrate (Fig. 12), chloride (Fig. 13) and sulfate (Fig. 14) were observed in groundwater samples collected from northern part of the study area. This suggests the influence of natural sources such as nitrogen leached from natural soils, volcanic minerals (e.g., apatite) and gases rather than anthropogenic activities. However, high concentrations of $\mathrm{NO}_{3}{ }^{-}, \mathrm{Cl}^{-}$and $\mathrm{SO}_{4}{ }^{2-}$ were observed in wells and springs (Figs. 12, 13, 14) located in highly populated urban areas (south of the study area) where the use of pit latrine and soak-away pit as sanitary facilities are common. Additionally, effluent from a combined domestic and industrial wastewater treatment plant (waste stabilization ponds) is being used for irrigation purpose in southern part of the study area which is likely to cause groundwater contamination. Similar cases of groundwater contamination have been reported in Tanzania and other parts of the world (Elisante and Muzuka 2015; Kaown et al. 2009; Mato and Kaseva 1999; Nkotagu 1996). In most cases, these wastes are discharged haphazardly to the environment (Couth and Trois 2011; Laramee and Davis 2013) or due to underground leakage from pit latrine, septic tanks and soak-away pit which are common sanitary facilities in the study area and Tanzania at large (Chaggu et al. 2002; Jenkins et al. 2014).
Moreover, water samples collected from northwest and western part of the study area commonly known as Ngaramtoni and Magereza showed relatively high concentrations of both $\mathrm{Cl}^{-}$(Fig. 13) and $\mathrm{SO}_{4}{ }^{2-}$ (Fig. 14). The area is dominated by cultivation of coffee, wheat, sunflower, maize, and beans. Therefore, fertilizer application and uncontrolled waste disposal mainly domestic sewage may have also contributed to these constituents in groundwater. Generally, the quality of groundwater with respect to $\mathrm{NO}_{3}{ }^{-}, \mathrm{Cl}^{-}$and $\mathrm{SO}_{4}{ }^{2-}$ in the study area was generally good as the concentrations are still fairly below the recommended WHO guidelines with exception of samples S04, S05 and W20 which recorded high nitrate levels $17.3,10.9$ and $10.1 \mathrm{mg} / \mathrm{l}$, respectively, possibly caused by human activities.

\section{Conclusions}

The hydrogeochemical assessment results and distribution of groundwater major cations $\left(\mathrm{Na}^{+}, \mathrm{Ca}^{2+}, \mathrm{K}^{+}, \mathrm{Mg}^{2+}\right)$ and anions $\left(\mathrm{HCO}_{3}{ }^{-}, \mathrm{Cl}^{-}, \mathrm{SO}_{4}{ }^{2-}, \mathrm{F}^{-}\right)$in the study area indicate that groundwater chemistry is mainly influenced by aquifer lithology than anthropogenic activities. Groundwater in the study area is dominated by sodium and bicarbonate ions which define the general composition of the water type to be $\mathrm{Na}-\mathrm{K}-\mathrm{HCO}_{3}$. With exception of fluoride, the quality of groundwater is generally suitable for drinking purpose and other socioeconomic uses. Based on the hydrogeological investigation, two potential aquifers (volcanic sediment and weathered/fractured formation) have been identified both having substantial yield. Generally, the aquifers yield water containing significant concentration of fluoride exceeding WHO guidelines. Fluoride concentrations were higher than WHO guidelines $(1.5 \mathrm{mg} / \mathrm{l})$ and Tanzanian standards ( $4.0 \mathrm{mg} / \mathrm{l})$ by 82 and $36 \%$ of the analyzed groundwater samples, respectively. The northern and northwestern parts of the study area indicated high fluoride concentrations in both well and spring waters than southern zone. As mentioned earlier, high fluoride concentration in northern and northwestern parts is probably due to dominance in basaltic formation and other fluoride-rich volcanic materials such as lahars and volcanic ash which are known to contain and release significant amount of fluoride into groundwater in the region. However, a detailed geological studies need to be conducted to precisely inform the entire spectrum of fluoride distribution in the study area. Groundwater abstracted from the southern part of the study area is of better quality for human consumption than northern zones which is at high elevation on the foot of Mt. Meru. The influence 
of anthropogenic pollutants was observed in shallow wells and spring sources. This was evidenced by relatively high concentrations of nitrate, chloride and sulfate in samples collected from sources close to populated urban areas, wastewater effluent disposal zones, and croplands. Spring water sources should be protected from anthropogenic activities as they produce water of good quality in terms of key chemical parameters including fluoride which seems to be critical in the study area.

Acknowledgements The authors wish to appreciate the technical support offered by Arusha Urban Water Supply and Sanitation Authority (AUWSA) during filed work (sample collection). We also extend our sincere gratitude to Laboratory Scientists from Water and Environmental Sciences and Engineering Laboratory at the Nelson Mandela African Institution of Science and Technology and Ardhi University particularly Department of Environmental Engineering for their technical supports during various chemical analyses of water samples.

Funding This work was supported by the Government of Tanzania through Commission for Science and Technology (COSTECH).

\section{Compliance with ethical standards}

Conflict of interest The authors declare that they have no conflict of interest.

Open Access This article is distributed under the terms of the Creative Commons Attribution 4.0 International License (http://creativeco mmons.org/licenses/by/4.0/), which permits unrestricted use, distribution, and reproduction in any medium, provided you give appropriate credit to the original author(s) and the source, provide a link to the Creative Commons license, and indicate if changes were made.

\section{Appendix: Water quality distribution in the study area}

See Figs. 11, 12, 13 and 14. 


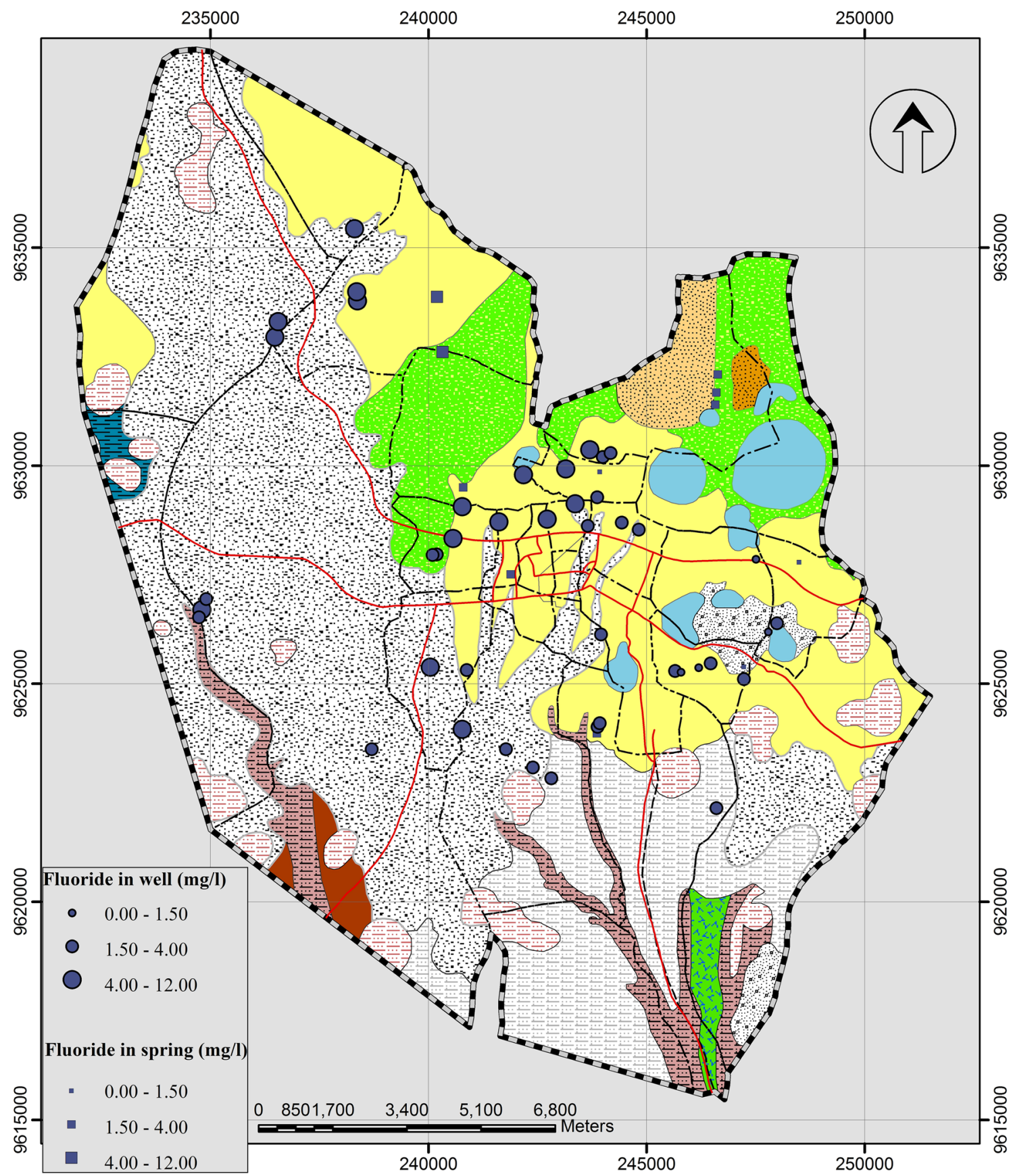

\begin{tabular}{|c|c|c|}
\hline \multirow[b]{2}{*}{ Legend } & Geological Formation & \\
\hline & Alluvium and Alluvial fan Deposits & Mantilg ash, (Main core group ) \\
\hline Boreholes & $=$ Black/orev shrinkin $\sigma$ soil with calcreous nodules & $\square$ Mantling ash \\
\hline & 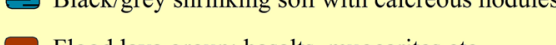 & Nephelinite lavas and breccias \\
\hline Roads & Flood lava group; basalts, mugearites etc, & $\square$ Parasitic cones, Alkaline \\
\hline Study area boundary & Lahars of various ages & $\begin{array}{l}\text { Parasitic cones, } \\
\text { basic-ankaramitic-basaltic lavas and scoria }\end{array}$ \\
\hline Wards boundary & $\begin{array}{l}\text { Pyroclastics with surbodinate nephelinitic and } \\
\text { phonolitic lavas }\end{array}$ & Brown/red soil on volcanic rock \\
\hline
\end{tabular}

Fig. 11 Fluoride spatial distribution map for spring and well waters 


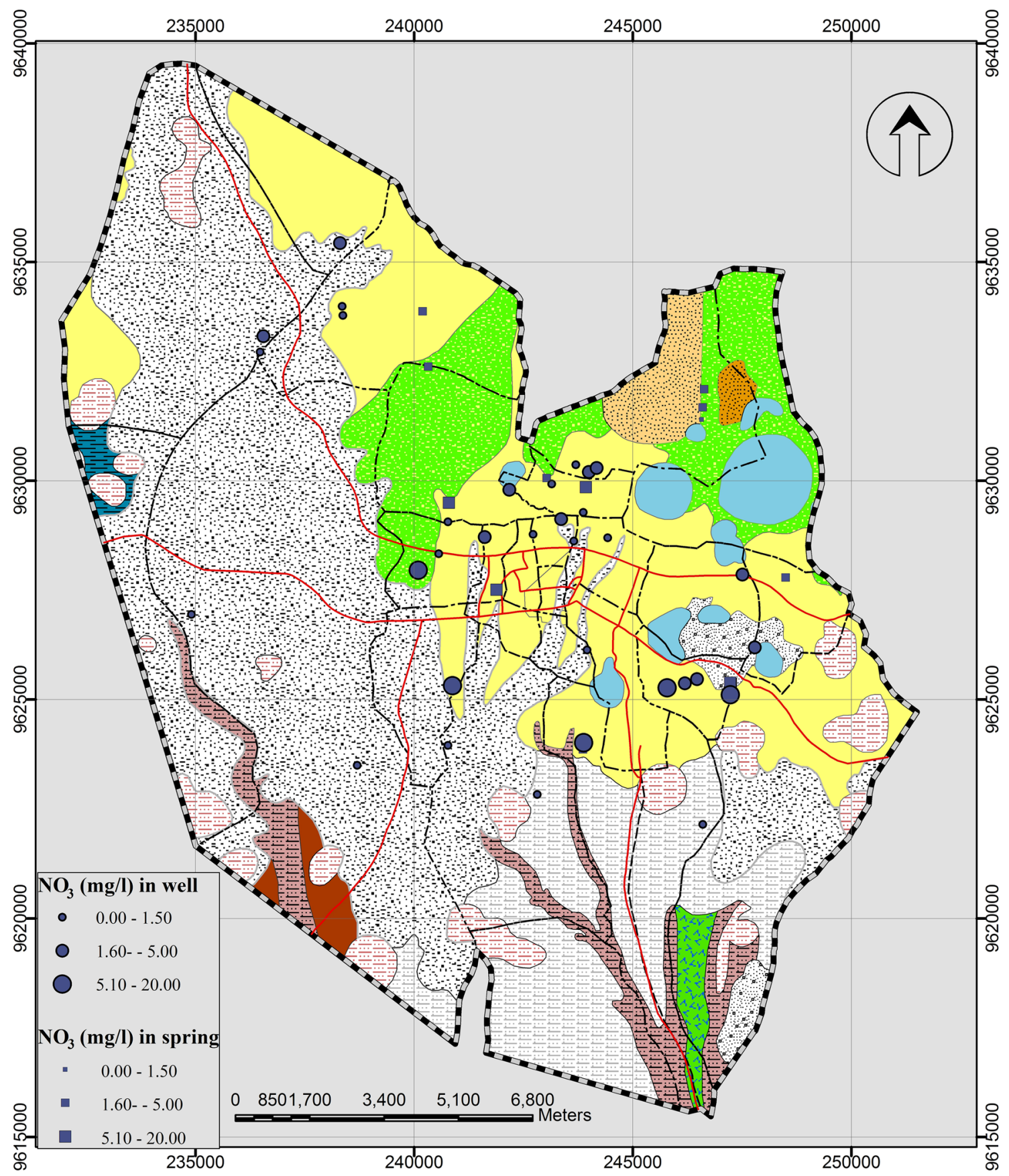

\begin{tabular}{|c|c|c|}
\hline \multicolumn{3}{|c|}{ Geological Formation } \\
\hline Springs & $\because$ Alluvium and Alluvial fan Deposits & Mantilg ash, (Main core group ) \\
\hline Boreholes & Black/grey shrinking soil with calcreous nodules & $\square$ Mantling ash \\
\hline & & तephelinite lavas and breccias \\
\hline Roads & Flood lava group; basalts, mugearites etc, & $\square$ Parasitic cones, Alkaline \\
\hline Study area boundary & Lahars of various ages & $\begin{array}{l}\text { Parasitic cones, } \\
\text { basic-ankaramitic-basaltic lavas and scoria }\end{array}$ \\
\hline Wards boundary & $\begin{array}{l}\text { A. Pyroclastics with surbodinate nephelinitic and } \\
\text { phonolitic lavas }\end{array}$ & Brown/red soil on volcanic rock \\
\hline
\end{tabular}

Fig. 12 Nitrate distribution map for spring and well waters 


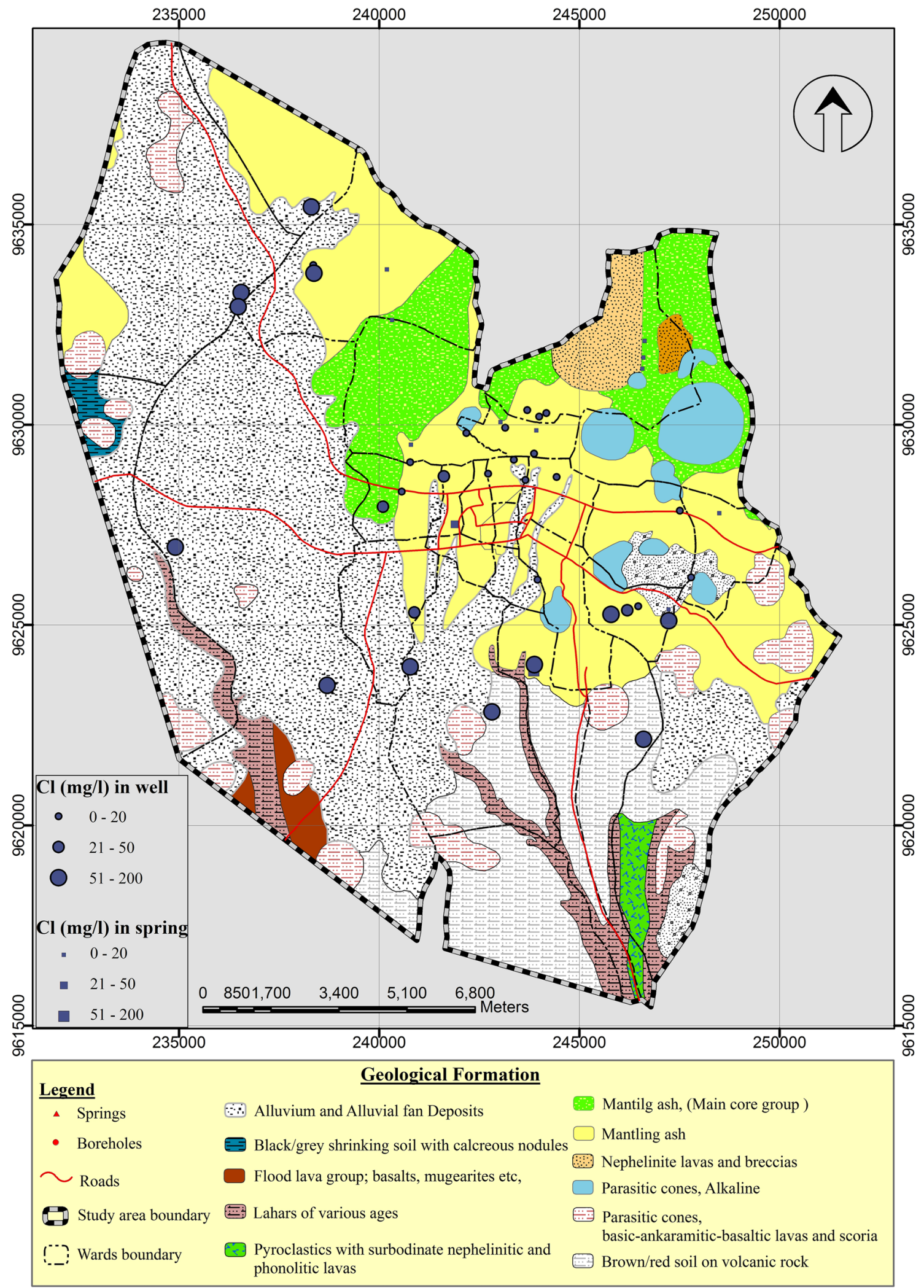

Fig. 13 Chloride distribution map for spring and well waters 


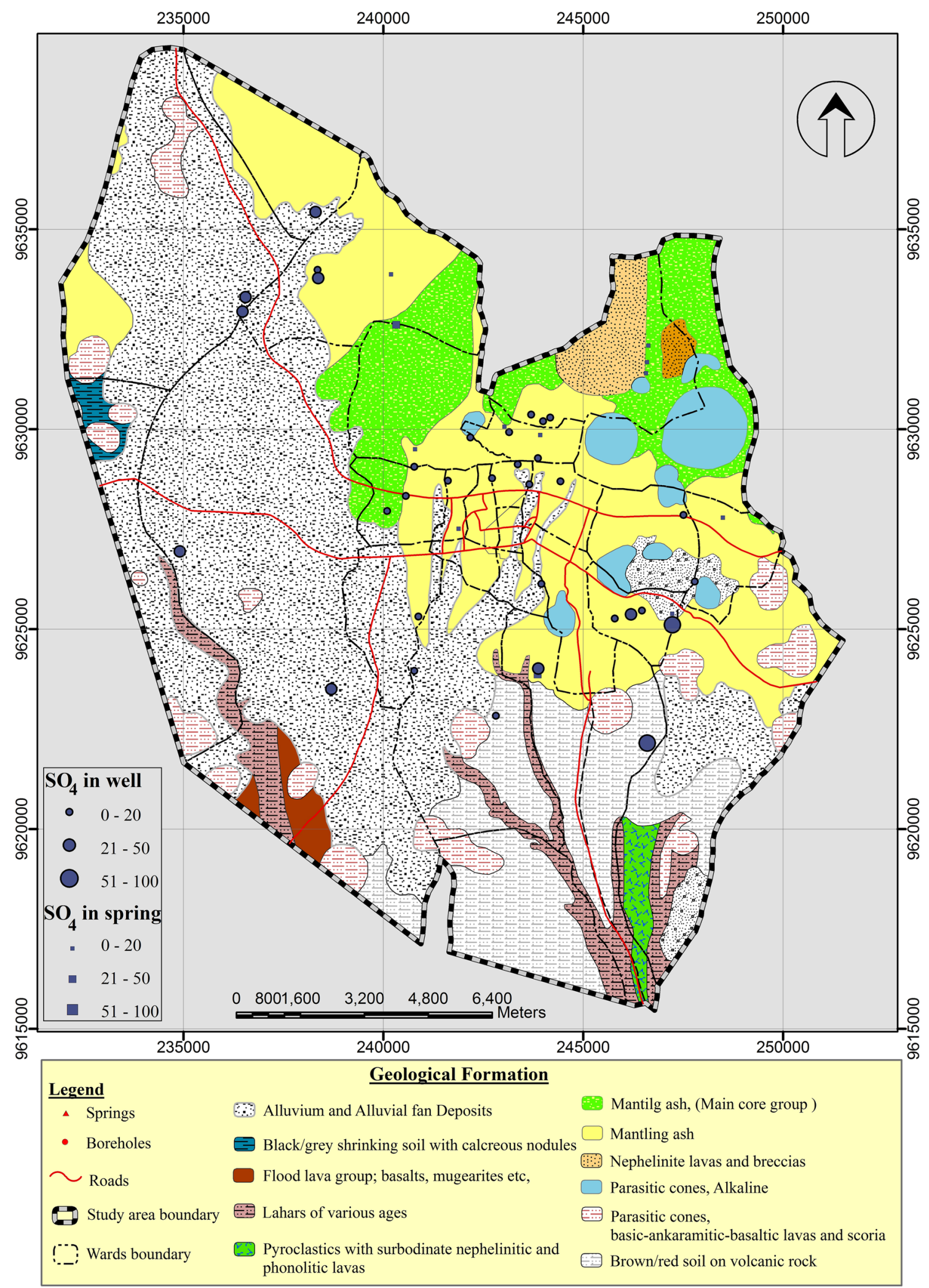

Fig. 14 Sulphate distribution map for spring and well waters 


\section{References}

AA.VV. (1983) Arusha Quarter Degree Sheet 55 scale 1:125,000, Geological Survey of Tanzania

Adelana SMA (2005) Nitrate health effects. In: Lehr JH, Keeley J (eds) Water encyclopedia, vol 4. Wiley

Ako AA et al (2011) Evaluation of groundwater quality and its suitability for drinking, domestic, and agricultural uses in the Banana Plain (Mbanga, Njombe, Penja) of the Cameroon Volcanic Line. Environ Geochem Health 33:559-575

American Public Health Association A (2012) Standard methods for the examination of water and wastewater. American Water Works Association, Washington, DC

Anderson J, Baker M, Bede J (2012) Reducing emissions from deforestation and forest degradation in the Yaeda Valley, Northern Tanzania. Carbontanzania, Unpublished Report

AUWSA (2014) Medium term strategic plan (2015-2020). AUWSA, Arusha

Bretzler A, Osenbrück K, Gloaguen R, Ruprecht JS, Kebede S, Stadler $S$ (2011) Groundwater origin and flow dynamics in active rift systems - a multi-isotope approach in the Main Ethiopian Rift. J Hydrol 402:274-289

Brown C, Lall U (2006) Water and economic development: the role of variability and a framework for resilience. Natural Resources Forum, Wiley Online Library, vol 4. Blackwell Publishing Ltd, Hoboken, pp 306-317

Bryan K (1919) Classification of springs. J Geol 27:522-561

Cerling TE, Pederson B, Von Damm K (1989) Sodium-calcium ion exchange in the weathering of shales: implications for global weathering budgets. Geology 17:552-554

Chae G-T et al (2007) Fluorine geochemistry in bedrock groundwater of South Korea. Sci Total Environ 385:272-283

Chaggu E, Mashauri D, Van Buuren J, Sanders W, Lettinga G (2002) Excreta disposal in Dar-es-Salaam. Environ Manage 30:0609-0620

Changming L, Jingjie Y, Kendy E (2001) Groundwater exploitation and its impact on the environment in the North China Plain. Water Int 26:265-272

Cheema M (2016) Agricultural production, water use and food availability in Pakistan: historical trends, and projections to 2050. Agric Water Manag 179:34-46

Chenoweth J (2008) Minimum water requirement for social and economic development. Desalination 229:245-256

Couth R, Trois C (2011) Waste management activities and carbon emissions in Africa. Waste Manag 31:131-137

Currell MJ, Han D, Chen Z, Cartwright I (2012) Sustainability of groundwater usage in northern China: dependence on palaeowaters and effects on water quality, quantity and ecosystem health. Hydrol Process 26:4050-4066

Custodio E (2002) Aquifer overexploitation: what does it mean? Hydrogeol J 10:254-277

Davidson I, Ravi S (2005) Agglomerative hierarchical clustering with constraints: theoretical and empirical results. In: European conference on principles of data mining and knowledge discovery, Springer, pp 59-70

Delinom RM (2008) Groundwater management issues in the Greater Jakarta area, Indonesia. TERC Bull Univ Tsukuba 8:40-54

Dixon B (2005) Groundwater vulnerability mapping: a GIS and fuzzy rule based integrated tool. Appl Geogr 25:327-347

Drechsel P, Dongus S (2010) Dynamics and sustainability of urban agriculture: examples from sub-Saharan Africa. Sustain Sci 5:69-78

Elisante E, Muzuka AN (2015) Occurrence of nitrate in Tanzanian groundwater aquifers: a review. Appl Water Sci 1:1-17
Fan AM, Steinberg VE (1996) Health implications of nitrate and nitrite in drinking water: an update on methemoglobinemia occurrence and reproductive and developmental toxicity. Regul Toxicol Pharmacol 23:35-43

Fenta AA, Kifle A, Gebreyohannes T, Hailu G (2015) Spatial analysis of groundwater potential using remote sensing and GIS-based multi-criteria evaluation in Raya Valley, northern Ethiopia. Hydrogeol J 23:195-206

Fitts CR (2002) Groundwater science. Academic Press, Cambridge

Fritz SJ (1994) A survey of charge-balance errors on published analyses of potable ground and surface waters. Ground Water 32:539-546

Ghiglieri G, Balia R, Oggiano G, Ardau F, Pittalis D (2008) Hydrogeological and geophysical investigations for groundwater in the Arumeru District (Northern Tanzania). Rend Online SGI 2:431-432

Ghiglieri G, Balia R, Oggiano G, Pittalis D (2010) Prospecting for safe (low fluoride) groundwater in the Eastern African Rift: the Arumeru District (Northern Tanzania). Hydrol Earth Syst Sci Dis 14:1081-1091

Ghiglieri G, Pittalis D, Cerri G, Oggiano G (2012) Hydrogeology and hydrogeochemistry of an alkaline volcanic area: the NE Mt. Meru slope (East African Rift-Northern Tanzania). Hydrol Earth Syst Sci 16:529-541

GITEC, WEMA (2011) Groundwater assessment of the Pangani Basin, Tanzania. The Pangani Basin Water Board (PBWB) and International Union for Conservation of Nature (IUCN)

Gizaw B (1996) The origin of high bicarbonate and fluoride concentrations in waters of the Main Ethiopian Rift Valley, East African Rift system. J Afr Earth Sc 22:391-402

Gleeson T, Alley WM, Allen DM, Sophocleous MA, Zhou Y, Taniguchi M, VanderSteen J (2012) Towards sustainable groundwater use: setting long-term goals, backcasting, and managing adaptively. Ground Water 50:19-26

Gleeson T, Befus KM, Jasechko S, Luijendijk E, Cardenas MB (2016) The global volume and distribution of modern groundwater. Nat Geosci 9:161

Guo H, Zhang Y, Xing L, Jia Y (2012) Spatial variation in arsenic and fluoride concentrations of shallow groundwater from the town of Shahai in the Hetao basin, Inner Mongolia. Appl Geochem 27:2187-2196

Hammer Ø, Harper D, Ryan P (2001) Paleontological statistics software: package for education and data analysis. Palaeontol Electron $4: 9$

Heathwaite A (2010) Multiple stressors on water availability at global to catchment scales: understanding human impact on nutrient cycles to protect water quality and water availability in the long term. Freshw Biol 55:241-257

Hellar-Kihampa H, De Wael K, Lugwisha E, Van Grieken R (2013) Water quality assessment in the Pangani River basin, Tanzania: natural and anthropogenic influences on the concentrations of nutrients and inorganic ions. Int J River Basin Manag 11:55-75

Ishaku J, Ankidawa B, Abbo A (2015) Groundwater quality and hydrogeochemistry of Toungo Area, Adamawa State, North Eastern Nigeria. Am J Min Metall 3:63-73

Jenkins M, Cumming O, Scott B, Cairncross S (2014) Beyond 'improved' towards 'safe and sustainable' urban sanitation: assessing the design, management and functionality of sanitation in poor communities of Dar es Salaam, Tanzania. J Water Sanitat Hyg Dev 4:131-141

Jha MK, Chowdhury A, Chowdary V, Peiffer S (2007) Groundwater management and development by integrated remote sensing and geographic information systems: prospects and constraints. Water Resour Manage 21:427-467

Kaihura F, Stocking M, Kahembe E (2001) Soil management and agrodiversity: a case study from Arumeru, Arusha, Tanzania. In: Proceedings of the symposium on managing biodiversity in agricultural systems, Montreal 
Kaown D, Koh D-C, Mayer B, Lee K-K (2009) Identification of nitrate and sulfate sources in groundwater using dual stable isotope approaches for an agricultural area with different land use (Chuncheon, mid-eastern Korea). Agr Ecosyst Environ 132:223-231

Kashaigili JJ (2010) Assessment of groundwater availability and its current and potential use and impacts in Tanzania Report prepared for the International Water Management Institute (IWMI), Colombo, Sri Lanka

Kijazi AL, Reason C (2009) Analysis of the 2006 floods over northern Tanzania. Int J Climatol 29:955-970

Kløve B et al (2014) Climate change impacts on groundwater and dependent ecosystems. J Hydrol 518:250-266

Komakech HC, Van Der Zaag P, Van Koppen B (2012) The last will be first: water transfers from agriculture to cities in the Pangani river basin, Tanzania. Water Altern 5:700

Kump LR, Brantley SL, Arthur MA (2000) Chemical weathering, atmospheric $\mathrm{CO}_{2}$, and climate. Annu Rev Earth Planet Sci 28:611-667

Laramee J, Davis J (2013) Economic and environmental impacts of domestic bio-digesters: evidence from Arusha, Tanzania. Energy Sustain Dev 17:296-304

Mato R, Kaseva M (1999) Critical review of industrial and medical waste practices in Dar es Salaam City Resources. Conserv Recycl 25:271-287

Mbonile MJ (2005) Migration and intensification of water conflicts in the Pangani Basin, Tanzania. Habitat Int 29:41-67

Mooi E, Sarstedt M (2010) Cluster analysis. Springer, Berlin

Moturi WK, Tole MP, Davies TC (2002) The contribution of drinking water towards dental fluorosis: a case study of Njoro Division, Nakuru District, Kenya. Environ Geochem Health 24:123-130

Nanyaro J, Aswathanarayana U, Mungure J, Lahermo P (1984) A geochemical model for the abnormal fluoride concentrations in waters in parts of northern Tanzania. J Afr Earth Sc 2:129-140

NBS (2013) The 2012 population and housing census: population distribution by administrative areas. Nation Bureau of Statistics (NBS) and Office of the Chief Government Statistician, United Republic of Tanzania

Nkotagu H (1996) Origins of high nitrate in groundwater in Tanzania. J Afr Earth Sc 22:471-478

Noel S, Soussan J, Barron J (2015) Water and poverty linkages in Africa: Tanzania case study

Olobaniyi S, Owoyemi F (2006) Characterization by factor analysis of the chemical facies of groundwater in the Deltaic plain sands Aquifer of Warri Western Niger Delta, Nigeria African. J Sci Technol Sci Eng Ser 7:73-81

Ong'or BTI, Long-cang S (2007) Groundwater overdraft vulnerability and environmental impact assessment in Arusha. Environ Geol 51:1171-1176

Piper AM (1944) A graphic procedure in the geochemical interpretation of water-analyses Eos. Trans Am Geophys Union 25:914-928

Rafique T, Naseem S, Usmani TH, Bashir E, Khan FA, Bhanger MI (2009) Geochemical factors controlling the occurrence of high fluoride groundwater in the Nagar Parkar area, Sindh, Pakistan. J Hazard Mater 171:424-430

Rahmati O, Samani AN, Mahdavi M, Pourghasemi HR, Zeinivand $\mathrm{H}$ (2015) Groundwater potential mapping at Kurdistan region of Iran using analytic hierarchy process and GIS. Arab J Geosci 8:7059-7071

Reddy VR (2005) Costs of resource depletion externalities: a study of groundwater overexploitation in Andhra Pradesh, India. Environ Dev Econ 10:533-556

Roberts MA (2002) The geochemical and volcanological evolution of the Mt. Meru Region, Northern Tanzania, A Dissertation submitted for the Award of PhD Degree at the University of Cambridge, UK
Sadashivaiah C, Ramakrishnaiah C, Ranganna G (2008) Hydrochemical analysis and evaluation of groundwater quality in Tumkur Taluk, Karnataka State, India. Int J Environ Res Public Health 5:158-164

Saxena V, Ahmed S (2001) Dissolution of fluoride in groundwater: a water-rock interaction study. Environ Geol 40:1084-1087

Schmoll O (2006) Protecting groundwater for health: managing the quality of drinking-water sources. World Health Organization, Geneva

Schwarzenbach RP, Egli T, Hofstetter TB, Von Gunten U, Wehrli B (2010) Global water pollution and human health. Annu Rev Environ Resour 35:109-136

Srinivas Y, Hudson OD, Stanley RA, Chandrasekar N (2014) Quality assessment and hydrogeochemical characteristics of groundwater in Agastheeswaram taluk, Kanyakumari district, Tamil Nadu, India. Chin J Geochem 33:221-235

Srinivasamoorthy K, Chidambaram S, Prasanna M, Vasanthavihar M, Peter J, Anandhan P (2008) Identification of major sources controlling groundwater chemistry from a hard rock terrain-a case study from Mettur taluk, Salem district, Tamil Nadu, India. J Earth Syst Sci 117:49-58

Srinivasamoorthy K, Vijayaraghavan K, Vasanthavigar M, Sarma S, Chidambaram S, Anandhan P, Manivannan R (2012) Assessment of groundwater quality with special emphasis on fluoride contamination in crystalline bed rock aquifers of Mettur region, Tamilnadu, India. Arab J Geosci 5:83-94

Sundaram B, Feitz A, Caritat Pd, Plazinska A, Brodie R, Coram J, Ransley T (2009) Groundwater sampling and analysis-a field guide. Geosci Aust Record 27:95

Taylor RG, Burgess WG, Shamsudduha M, Zahid A, Lapworth D, Ahmed K, Mukherjee A, Nowreen S (2014) Deep groundwater in the Bengal Mega-Delta: new evidence of aquifer hydraulics and the influence of intensive abstraction. British Geological Survey Open Report, OR/14/070

Utom AU, Odoh BI, Egboka BC (2013) Assessment of hydrogeochemical characteristics of groundwater quality in the vicinity of Okpara coal and Obwetti fireclay mines, near Enugu town, Nigeria. Appl Water Sci 3:271-283

Venetsanou P, Voudouris K, Kazakis N, Mattas C (2015) Impacts of urbanization, agriculture and touristic development on groundwater resources in the eastern part of Thermaikos Gulf, North Greece. Eur Water 51:3-13

Venkatramanan S, Chung S, Ramkumar T, Gnanachandrasamy G, Vasudevan S, Lee S (2015) Application of GIS and hydrogeochemistry of groundwater pollution status of Nagapattinam district of Tamil Nadu, India. Environ Earth Sci 73:4429-4442

Wada Y, van Beek LP, van Kempen CM, Reckman JW, Vasak S, Bierkens MF (2010) Global depletion of groundwater resources. Geophys Res Lett 37:20

Wilkinson P, Mitchell J, Cattermole P, Downie C (1986) Volcanic chronology of the Men-Kilimanjaro region, Northern Tanzania. J Geol Soc 143:601-605

Zorita E, Tilya FF (2002) Rainfall variability in Northern Tanzania in the March-May season (long rains) and its links to large-scale climate forcing. Climate Res 20:31-40

Publisher's Note Springer Nature remains neutral with regard to jurisdictional claims in published maps and institutional affiliations. 